\title{
Joint and Cross-border Patents as Proxies for International Technology Diffusion
}

Instituto

Complutense

de Análisis

Económico

\author{
Chia-Lin Chang \\ Department of Applied Economics \\ Department of Finance \\ National Chung Hsing University, Taiwan
}

\section{Michael McAleer}

Department of Quantitative Finance, College of Technology Management, National Tsing Hua University, Taiwan and Econometric Institute, Erasmus School of Economics, Erasmus University Rotterdam, The Netherlands and Tinbergen Institute, The Netherlands and Department of Quantitative Economics, Complutense University of Madrid, Spain

\author{
Ju-Ting Tang \\ Department of Applied Economics \\ National Chung Hsing University, Taiwan
}

\begin{abstract}
With the advent of globalization, economic and financial interactions among countries have become widespread. Given technological advancements, the factors of production can no longer be considered to be just labor and capital. In the pursuit of economic growth, every country has sensibly invested in international cooperation, learning, innovation, technology diffusion and knowledge, and outward direct investment. In this paper, we use a panel data set of 40 countries from 1981 to 2008 and a negative binomial model, using a novel set of cross-border patents and joint patents as proxy variables for technology diffusion, in order to investigate such diffusion. The empirical results suggest that, if it is desired to shift from foreign to domestic technology, it is necessary to increase expenditure on R\&D for business enterprises and higher education, exports and technology. If the focus is on increasing bilateral technology diffusion, it is necessary to increase expenditure on R\&D for higher education and technology. It is also found that outward foreign direct investment has no significant impact on either joint or cross-border patents, whereas inward foreign direct investment has a significant negative impact on cross-border patents but no impact on joint patents. Moreover, government expenditure on higher education has a significant impact on both cross-border and joint patents.
\end{abstract}

Keywords International Technology Diffusion, Exports, Imports, Joint Patent, Cross-border Patent, R\&D, Negative Binomial Panel Data.

JEL Classification F14, F21, 030, 057.

\section{Working Paper no 1702 December, 2016}

UNIVERSIDAD

COMPLUTENSE

MADRID

ISSN: 2341-2356

WEB DE LA COLECCIÓN: http://www.ucm.es/fundamentos-analisis-economico2/documentos-de-trabajo-del-icaeWorking papers are in draft form and are distributed for discussion. It may not be reproduced without permission of the author/s. 


\title{
Joint and Cross-border Patents as Proxies for International Technology Diffusion*
}

\author{
Chia-Lin Chang \\ Department of Applied Economics \\ Department of Finance \\ National Chung Hsing University, Taiwan \\ Michael McAleer \\ Department of Quantitative Finance \\ National Tsing Hua University, Taiwan \\ and \\ Econometric Institute, Erasmus School of Economics \\ Erasmus University Rotterdam, The Netherlands \\ and \\ Department of Quantitative Economics \\ Complutense University of Madrid, Spain \\ and \\ Institute of Advanced Sciences \\ Yokohama National University, Japan \\ Ju-Ting Tang \\ Department of Applied Economics \\ National Chung Hsing University, Taiwan
}

Revised: December 2016

* For financial support, the first author wishes to thank the National Science Council, Ministry of Science and Technology (MOST), Taiwan, and the second author is most grateful to the Australian Research Council and the National Science Council, Ministry of Science and Technology (MOST), Taiwan. 


\begin{abstract}
With the advent of globalization, economic and financial interactions among countries have become widespread. Given technological advancements, the factors of production can no longer be considered to be just labor and capital. In the pursuit of economic growth, every country has sensibly invested in international cooperation, learning, innovation, technology diffusion and knowledge, and outward direct investment. In this paper, we use a panel data set of 40 countries from 1981 to 2008 and a negative binomial model, using a novel set of cross-border patents and joint patents as proxy variables for technology diffusion, in order to investigate such diffusion. The empirical results suggest that, if it is desired to shift from foreign to domestic technology, it is necessary to increase expenditure on $R \& D$ for business enterprises and higher education, exports and technology. If the focus is on increasing bilateral technology diffusion, it is necessary to increase expenditure on $R \& D$ for higher education and technology. It is also found that outward foreign direct investment has no significant impact on either joint or cross-border patents, whereas inward foreign direct investment has a significant negative impact on cross-border patents but no impact on joint patents. Moreover, government expenditure on higher education has a significant impact on both cross-border and joint patents.
\end{abstract}

Keywords: International Technology Diffusion, Exports, Imports, Joint Patent, Cross-border Patent, R\&D, Negative Binomial Panel Data.

JEL: F14, F21, O30, O57. 


\section{Introduction}

With advances in technology and communications, the boundaries between countries have become blurred. In the increasingly globalized market, multinational corporations are, through free trade and foreign direct investment, exchanging capital, goods, services and knowledge across borders. As a result, countries have become increasingly dependent economically on each other, as both enterprises and the countries themselves form competitive and cooperative relationships. For these reasons, to remain competitive in international markets, multinational companies are actively engaging in technology reform and innovation at the international level. This means that the key elements of business growth comprise not only traditional capital, equipment and labor, but also knowledge and the ability to employ and innovate in the area of technology. In the current globalized economic environment, these factors are of considerable importance to increasing business productivity and international competitiveness .

As each country has different levels of expertise and knowledge, multinational enterprises engage in international cooperation to acquire innovation technology and knowledge. By keeping their costs of research and development (R\&D) relatively low, they are enhancing their ability to adapt to international markets. In order to achieve the effects of technological progress, these enterprises are making every effort to acquire technology and to innovate. Thus, the competition taking place among economic activities at the international level indirectly results in the international spread of technology. In addition to the technology spillovers occurring as a result of the technology embodied in the trade in goods and services, these international 
technology spillover channels also include technology spillovers arising from purchases and sales of disembodied technology.

Technology diffusion can also be referred to as knowledge spillover. When defining knowledge and technology, it can be difficult to distinguish between them . Knowledge is typically produced by universities and research institutions. After application in the market place, and undergoing research and development, if knowledge has any economic value, it can then be called technology. At this point, knowledge will be able to contribute to a country's economic growth .

In the current economic environment, a country's ability to innovate has become an important factor in enhancing business productivity and national economic growth. The higher is the degree of national innovation, the more developed will be the technology and knowledge that the country itself owns. However, through international cooperation, a country may possibly obtain greater resources to enhance economic growth. In this paper, we use patent cooperation as an indicator to measure international cooperation.

This paper uses patent data to evaluate international innovation activities in order to obtain a technology diffusion trajectory. Patents constitute the output of a country's innovation activities. As patents are knowledge or technology for which application is made, and approval is obtained from the patent authorities, others do not have the right to steal them or engage in plagiarism in relation to them. In this sense, patents have economic value. Based on the premise that patents are the output of innovation, patents can be used to measure a country's creativity. In particular, by means of the information provided by the patent documents, it is possible to investigate the trajectory of technology flows in the process of innovation. In this 
way, it can be determined whether innovation is diffused through $R \& D$ cooperation, or through the movement of technology across borders, or from one enterprise to another . In addition, innovation may be influenced by outward or inward foreign direct investment.

Based on the above, this paper analyses the international technology spillover effects for merchandise trade through embodied technology, as well as those effects based on the trade in disembodied technology. We use different patent characteristics to examine the effect of international spillovers for a sample of 40 countries, which are classified as Organization for Economic Co-operation and Development (OECD) countries and non-OECD countries.

The remainder of the paper is organized as follows. Section 2 provides a review of the literature on embodied technology diffusion and disembodied technology diffusion. Section 3 presents the variables, data and sample statistics for the empirical analysis, Section 4 discusses the research methods and empirical model, Section 5 introduces the empirical results, and Section 6 provides concluding remarks and some suggestions for future research.

\section{Review of the Literature}

Technological spillovers can be used to advantage by enterprises, which will then generate positive external effects (Norman and Pepall, 2004). This will lead to an entire batch of enterprises within the cluster achieving technological progress, to changes in product design, and to production systems being upgraded or to the development of new customer-based results. In discussing the main channels of technology spillovers, Keller 
(2001) indicates that the primary channels are international trade and foreign direct investment, and that it is through such international trade and foreign investment behavior that a country will promote the international flow of technology. In addition, international technology spillovers are effective for enhancing the productivity of less developed countries. Moreover, the use of technology spillover externalities depends mainly on the countries themselves being able to understand and explain the knowledge and technology (Mancusi, 2008). This means that education is extremely important for human capital (see also Cassia and Colombelli (2008); Carr et al. (2001)).

In the following review of the literature, we focus on three main channels of technology diffusion in relation to merchandise trade, technology trade and individual learning capability.

\subsection{Embodied technology diffusion}

The earliest research on international trade and technology diffusion was by Coe and Helpman (1995), whose research indicated that international trade and technology diffusion are strongly linked. Based on economic growth theory, they used pooled time series cross-sectional data for 1971-1990 for 21 OECD countries plus Israel, and used $R \& D$ capital stock to denote the flow of technology. The empirical results indicated that productivity and the flow of technology are indeed closely linked, and that the flow of technology and the composition of imports (with imports arising from high-knowledge or low-knowledge countries) are positively related. The larger the share of imports, the more significant is the relationship so that, in more open economies, the influence of foreign $\mathrm{R} \& \mathrm{D}$ on productivity is greater. 
Following the Coe and Helpman (1995), many studies have discussed their results in detail. Research that focused the impact of industrialized countries' R\&D investment on the productivity of relatively less developed countries was examined by Coe et al. (1997, 2008). They use human capital to denote the flow of technology, but did not consider domestic R\&D capital stock (as the domestic R\&D stock of developing countries is relatively small, it can safely be ignored). Their empirical results from several developing countries confirm the results that foreign $\mathrm{R} \& \mathrm{D}$ spillovers are positively related to a country's total factor productivity.

Subsequently, Keller (1998) used counterfactual estimation to examine Coe and Helpman's (1995) conclusion regarding the importance of trade to international technology diffusion. The counterfactual estimation included using Monte Carlo experiments to estimate the trading partner's randomly assigned share of bilateral imports. This share of imports was, in turn, used as a weight to calculate the foreign $R \& D$ capital stock ${ }^{1}$, which was then used to simulate the data and perform a comparison with the results estimated by Coe and Helpman (1995).

The results of the empirical analysis indicated that, by using the randomly generated share of imports of the trading partner to serve as weights, the output elasticity of the spillovers of the foreign $R \& D$ stock was greater than the share of real imports used to calculate the foreign R\&D capital stock. Furthermore, using the share of imports to simulate the weight of the foreign R\&D stock to

\footnotetext{
1 In Coe and Helpman (1995), the R\&D capital stock is calculated by using the trading partner's domestic R\&D capital stock, with the share of imports as the weighted average of the weights. 
explain changes in a country's productivity led to superior results than those obtained by Coe and Helpman (1995), who used the shares of real imports as weights for their $R \& D$ results (which gave a relatively high $R^{2}$ value). These empirical findings indicate that using the estimated results of random data that are not related to international trade is superior to using real data.

There are also studies that have used import data that do not consist of all imports of goods and services, but which classify imports according to different kinds of imports, such as using imports of machinery or capital goods to examine their impact on knowledge spillovers. Keller (2000) used data on imports of machinery goods and productivity for 1970-1990 for eight OECD countries to expand upon Keller (1998)'s counterfactual estimation. By conducting Monte Carlo experiments to estimate the trading partner's randomly assigned bilateral import shares, Keller examines the impact of a country's imports of intermediate goods on productivity. The empirical results indicate that, if the share of imports between countries is uniform, the share of imports is unlikely to have an important bearing on the diffusion of technology . However, if a country's imports from a particular country account for a relatively large share of that country's imports, the share of imports will have an influence on technology diffusion.

Xu and Wang (1999) use panel data for 21 OECD countries for the 1983-1990, with imports of capital goods reflecting the importance of international technology spillover channels. Their results indicate that, when only imports of capital goods and not the imports of all manufactured goods are taken into account, the combination of imports will have a relatively large 
influence on international technology spillovers. Therefore, doubts may be raised regarding the results that imports are important to the diffusion of technology. Eaton and Kortum (1996) use cross-sectional data for 19 OECD countries for 1986-1988, and develop a productivity and patent technology diffusion growth model to explain the relative growth and productivity of the OECD countries. Their results indicate that, by controlling for distance and other influential factors, bilateral imports do not help in forecasting bilateral patent activity and indicators of international diffusion .

Clerides et al. (1998) use plant-level data for Columbia (1981-1991), Mexico (1986-1990), and Morocco (1984-1990) to examine the causal relationship between exports and productivity to see whether enterprises that become exporters will enhance the efficiency of enterprise learning. Their results do not provide evidence that export-oriented enterprises can achieve a learning effect by exporting.

Carr et al. (2001) argued that foreign direct investment frequently involves the transfer of technology between countries, which means that international trade and foreign direct investment indeed play an important role in international technology diffusion.

Recently, Chang et al. (2013) used triadic patents and single patents as proxy variables for innovation and a panel data for 37 countries for 1994-2005 to examine the impact of the main channels of international trade on domestic innovation. These channels are outward direct investment, inward direct investment, cross-border merges \& acquisitions (M\&A) by foreigners, R\&D expenditure, exports and imports. Their empirical results indicated that exports 
promote domestic innovation activities, and thereby enhance the domestic technology level, but the effect of imports on domestic innovation activities was insignificant. They also showed that the impact of inward direct investment on domestic innovation was negative.

Overall, many empirical studies have confirmed Coe and Helpman's (1995) hypothesis that foreign technology through trade serves as the channel for international technology spillovers for influencing the growth of total factor productivity (also see Lichtenberg et al. (1998); Branstetter (2001); Lee (2006); Woerter and Roper (2010); García et al. (2013) ).

\subsection{Disembodied technology diffusion}

Madsen (2007) uses data on technology imports and total factor productivity for 16 OECD countries for 1870-2004 to examine whether knowledge is disseminated through trade. The empirical results indicate that imports of technology and domestic knowledge have had a significant impact on total factor productivity over the past 135 years, and that $93 \%$ of the growth in total factor productivity growth over the past century has been due to technology imports .

The focus of the literature on firm level data such as the recent work of Chang and Robin (2006), uses panel data for a total of 27,754 enterprises in Taiwan's manufacturing sector for 1992-1995. It is found that, in most industries, $R \& D$ and technology imports frequently exhibit a complementary rather than a substituting relationship with each other. More recently, Chang and Robin (2012) examine the impact of R\&D and technology imports on firm 
performance against the background of Taiwan's manufacturing industry and industrial upgrading policy. They use the stochastic frontier model of Battese and Coelli $(1992,1995)$ to estimate a two-panel translog production function for 1992-1995 and 1997-2003. Their empirical results show that in most industries the impact of knowledge input is relatively noticeable in the second panel (1997-2003), indicating that the policy launched in 1991 to promote enterprise sales through innovation started to be effective in 1995. Thus, while innovation has become a key factor in improving sales, the impact of innovation can be interpreted differently in different industries. In traditional industries, the effect of innovation can be interpreted as the result of catching up with the world's frontier technology. Moreover, in the electronics or high-tech industry, innovation has led to the emergence of a new era in Taiwan that is characterized by specialization and knowledge intensity.

In a recent empirical study Hagedoor and Wang (2012) confirmed that internal and external $R \& D$, either through $R \& D$ alliances or acquisitions, are complementary innovation activities at higher levels of in-house R\&D investments. However, at lower levels of in-house R\&D investment efforts, internal and external R\&D are observed to be substitute strategic options.

\subsection{Individual learning cap ability and technology diffusion}

Due to different levels of development for each country, the ability to use and absorb knowledge can also vary. Mancusi (2008) used R\&D data and European Patent Office (EPO) patent application data for 14 OECD countries for 1978-2003 to examine how the productivity of less developed countries 
can be enhanced. The empirical findings indicated that international knowledge spillovers were effective in enhancing the productivity of less developed countries, and that using knowledge externalities resulting from international spillovers depended mainly on using the country's understanding of and ability to explain external knowledge. Geroski, Machin and Van Reenen (1993) used panel data for U.K. manufacturing for 1972-1983 and divided enterprises according to whether they were in innovative or non-innovative industries to examine the impact of major innovative activity on enterprise profitability. Their results indicated that the volume of innovation produced by enterprises had a positive impact on their profitability, but that the effect was not significant, on average. Innovative and non-innovative enterprises were consistently different from each other over the longer term in that innovative enterprises had a larger market share than non-innovative enterprises. Moreover, internally innovative enterprises were better able to understand and learn knowledge, giving them greater opportunities to benefit from receiving spillovers and also making them more competitive.

Cohen and Levinthal (1989) used Federal Trade Commission R\&D expenditure and sales data, and examined the traditional view that R\&D takes place to "produce a product (new information)" with the enterprise as the unit. Cohen and Levinthal (1989) argue that R\&D did not only exist to produce new information, but also to strengthen the enterprise's ability to use and absorb currently-held information. Their results indicated that the difficulty or ease to learn knowledge within the industry had an effect on R\&D expenditure, appropriability and technological opportunities, an outcome 
that differed from traditional results. In order to promote learning ability, one should stimulate $R \& D$ expenditure as, by stimulating $R \& D$ expenditure in this way, learning capabilities will increase, indicating that basic technical and scientific knowledge determine the ability to learn .

\section{Data and Variables}

In this paper, 40 countries are considered for 1981-2008, with countries divided into OECD and non-OECD countries. As the OECD was established in 1961, we divide the countries into those that joined as founding members in 1961 and those that acceded to OECD later. Details of the countries comprising the sample and the year in which they joined the OECD are given in Table 1.

\section{< Table 1 goes here >}

Patents are the output of innovation activities. Patent cooperation can be used to measure the extent to which countries cooperate with each other in regard to innovation, and refers to the internationalization of the diffusion of knowledge and invention activities. Moreover, the international patent cooperation emphasized in this paper is concerned with the information contained within the patent documents, which indicates the names of the inventor and the applicant. In most cases, the applicant may be an enterprise, an organization, a university or a research office, and in some cases an individual. The applicant has ownership of the patent. The patent document 
includes the residential addresses of both the inventor and the applicant, and it is from this information that the nationality of the inventor and the applicant can be ascertained. If the inventor and the applicant are from different countries, it is possible to track the flow of knowledge internationally through both of these countries. According to the OECD (2008), the number of patents based on collaboration between inventors and applicants of different nationalities have accounted for an increasingly large share of all patents in recent years. There are two main reasons for this, namely "creation of knowledge" and "search for knowledge".

We use the numbers of international patent cooperation as proxy variables of technology diffusion. Two types of international patent cooperation serve as dependent variables, namely Cross-border patents and Jointly-invented patents. Both types of international patent cooperation are the numbers of patents approved for 1981-2008 by the USPTO. ${ }^{2}$

(a) Cross-border patents (Cross patents): This refers to the number of patents owned by the home country that were invented by foreign inventors. That is, it refers to the number of patents that the patent applicants ${ }^{3}$ (patent owners) possess that were invented by foreign inventors. Cross-border patents are mainly the result of multinational enterprises engaging in international activities, such as where the applicant for a patent is a business group, while the inventor of the patent is an employee of one of the enterprise's foreign subsidiaries. In such circumstances, the international trajectory of

\footnotetext{
${ }^{2}$ USPTO, United States Patent and Trademark Office.

3 The patent applicant can be an enterprise, institution, university, research office or an individual.
} 
the technology and knowledge embodied in the patents can be tracked based on the countries of residence of the applicant and the inventor of the patent, and the extent to which domestic enterprises control the foreign invention can be evaluated. This can motivate both countries in regard to internationalization and R\&D activities, and so can serve as an indicator of patent cooperation .

(b) Jointly-invented patents (Joint patent): This refers to the number of patents in which the domestic inventor invented the patent with at least one foreign inventor, as one approach to international cooperation. As the expertise and knowledge possessed by the inventors of different countries are not the same, searching for different kinds of knowledge takes place across borders to overcome the lack of resources for innovation. R\&D cooperation among $R \& D$ personnel internationally can be found where enterprises enter into joint ventures with one another, or organizations cooperate (cooperation between universities or public research institutions), and hence indicate patent cooperation. An OECD (2008) research report observed that the share of this kind of patent cooperation rose from 5.8\% in 1990 to $7 \%$ in 2005, and that the extent of the international cooperation among large countries and small countries was markedly different. In Belgium, the Czech Republic, Ireland, Hungary and Poland, cooperation patents invented as a result of cooperation with foreign countries accounted for more than $30 \%$ of patents. On average, small and less developed countries participated more actively in international cooperation compared to highly-developed countries, reflecting their need to overcome the 
problems associated with the small size of their internal markets and their lack of a technology R\&D base. In large countries, the level of cooperation also varied. In France, Germany, the U.K. and the U.S.A., the proportions attributable to international cooperation ranged from $11 \%$ for the U.S.A. to $27 \%$ for the U.K. The shares of international cooperation for Japan and South Korea were relatively small. European countries exhibited a tendency to cooperate with other European countries. Australia, Canada, China, India, Israel, Japan, Korea, Mexico, and New Zealand, by and large, cooperated primarily with the U.S.A.

For international trade, we use imports as well as exports of goods and services of all domestic industries to examine the relationship between imports and exports of patents and international trade, and international investment. Chang, Chen, and McAleer (2010) conducted detailed research on the effects of foreign direct investment on triadic patents. This paper does not discuss foreign direct investment as an explanatory variable, but rather uses expenditure on and income from technology trade to measure the extent to which a country uses foreign technology and sells technology. For the innovation input, this study uses the country's gross expenditure on R\&D to measure the country's $R \& D$ input. In addition, we also subdivide the country's gross expenditure on R\&D into three categories, namely government agencies' expenditure on $R \& D$, business organizations' expenditure on $R \& D$, and $R \& D$ expenditure by higher education. This will allow discussion of the $\mathrm{R} \& \mathrm{D}$ input in greater detail in different domains, as well as an analysis of the impact of expenditure on R\&D on patents. Finally, in order to examine 
whether differences exist among OECD member countries, we also use a dummy variable.

The details of the explanatory variables are given below and are summarized in Table 2:

\section{< Table 2 goes here >}

(a) Imports (Import): This is measured by each country's foreign imports as a percentage of GDP. International trade is an important economic strategy of a country in relation to products that it is unable to produce itself, but which can be imported, and which can also increase the competitiveness of homogeneous products in the country, and promote exchange between countries .

(b) Exports (Export): This is measured by each country's exports to countries abroad as a percentage of GDP. Through exports of goods, a country can have contact with foreign enterprises and gain new knowledge and technology. The country can also learn which types of technology domestic enterprises lack and, to increase its international competitiveness, can encourage domestic enterprises to engage in $R \& D$.

(c) Expenditure on technology trade $(T P)$ : This is measured by the expenditure on technology trade as a percentage of GERD. It is defined as the amount expended on technology purchased from abroad (the technology input) through technological cooperation and technology licensing, which includes the following: 1. Patents (purchases and sales); 2. Patent 
licensing; 3. Expertise; 4. Model and design; 5. Trademarks. 6. Technical services; and 7. Enterprise R\&D expenditure commissioned abroad. This variable can be measured through the international flows of knowledge acquired through technology licensing or direct purchases of knowledge .

(d) Income from technology trade $(T R)$ : This is measured by the income from technology trade as a proportion of GERD, and is defined as the income from technology obtained through technical cooperation and technology licensing and sold abroad (that is, exports of technology). [ It consists of the same items and expenditure on technology trade as given in (c) above.]

(e) Inward foreign direct investment (FDI_in): This is measured as the amount of inward foreign direct investment as a percentage of GDP.

(f) Outward foreign direct investment (FDI_out): This is measured as the amount of outward foreign direct investment as a percentage of GDP.

(g) Gross domestic expenditure on R\&D (GERD): This is measured by the gross domestic R\&D expenditure as a percentage of GDP. It refers to the total $R \& D$ expenditure of the domestic sector for one year, and includes each domestic sector's foreign-funded $R \& D$ expenditure, but does not include payments made to fund $R \& D$ overseas. The total $R \& D$ expenditure can depict a country's engagement in innovative research, as input indicators of innovative development. Domestic R\&D expenditure can be decomposed into R\&D expenditure for several sectors, including business enterprise $R \& D$ expenditure, government agencies' R\&D 
expenditure, higher education $\mathrm{R} \& \mathrm{D}$ expenditure and private non-profit R\&D expenditure. However, due to data limitations, in this paper we have access to data for $R \& D$ expenditure for only the first three sectors discussed above, namely (h), (i) and (j), as outlined below.

(h) Business enterprise expenditure on R\&D (BERD): This is measured by $R \& D$ expenditure by business enterprises as a percentage of GDP.

(i) Government agencies' expenditure on R\&D (GOVERD): This is measured by R\&D expenditure by government agencies as a percentage of GDP .

(j) Higher education expenditure on R\&D (HERD): This is measured by $R \& D$ expenditure by higher education as a percentage of GDP.

(k) Dummy variables are used to distinguish OECD countries from non-OECD countries. If a country is assigned a value of 1 , it is an OECD country with a value of 0 indicating a non-OECD country. As the OECD was established in 1961, OECD countries can be classified into those countries that joined OECD as founding members in 1961 and those that joined the OECD later. The sample period in this paper is 1981-2008.

The import and export data are obtained from the World Bank, while the data for patents, the volume of technology trade and $R \& D$ expenditure are sourced from the OECD, for 1981-2008.

Tables 3 presents descriptive statistics for the variables, and includes data for the mean, standard deviation, and minimum and maximum values. From Table 3, it can be seen that the standard deviations of the cross-border patents and jointly-invented patents are always greater than their corresponding means, 
indicating that the data are characterized by overdispersion. ${ }^{4}$ This is very closely related to our selection of the negative binomial model for estimation, which will be explained in detail below.

\section{< Table 3 goes here >}

From Table 3, it can be seen that the mean values of imports and exports as a proportion of GDP is in the region of $26 \%{ }^{5}$ This shows that, when international trade takes place frequently, the relationships between countries are likely to be very close. Expenditure on technology trade as a proportion of total domestic $\mathrm{R} \& \mathrm{D}$ expenditure is, on average, around $57 \%$, while income from technology trade as a proportion of GERD is, on average, about $42 \%$, indicating the existence of technology interdependence between countries. R\&D expenditures for different sectors as a proportion of a country's GDP are, in descending order, $0.98 \%$ for business enterprise $R \& D$ expenditure, followed by $0.33 \%$ for higher education $R \& D$ expenditure, and finally $0.25 \%$ for $R \& D$ expenditure by government agencies. From these results, it can be inferred that a country's innovation arises mainly from its business enterprise $R \& D$, followed by R\&D from universities or research institutions.

\section{Empirical Model}

${ }^{4}$ Overdispersion refers to the situation where the variance is greater than the mean.

${ }^{5} 0.1490602+0.1163706=0.2654308$. 
The patent data used here consist of count data, the data type being panel data. The negative binomial model is chosen for estimation in this paper. Before estimation, it is necessary to pay attention to two limitations of the model, as given in below:

(a) The data used here are count data and overdispersion must exist. This means that the variances of the explanatory variables are greater than the corresponding means. From Table 4, it can be seen that, for the count data for each of the two patent variables, the variances are greater than their means, so that overdispersion exists .

(b) The problem of zero inflation is not inherent in the data. By zero inflation is meant that the count data are characterized by an excessive number of zeros, leading to bias in the estimated results. Table 4 lists the proportions of the total observations for the three explanatory variables for which the observations are zero. It can be seen that zero observations account for only a very small share of the number of observations for each of the three variables. Therefore, the zero inflation issue is not a problem in the data set used here.

\section{< Table 4 goes here >}

\subsection{Negative binomial fixed effects model}

Hausman et al. (1984) argue that, when the type of data used consists of panel data, different results are obtained in developing the estimation model when the Poisson model and the negative binomial model are used for the 
relationship between patents and $R \& D$ expenditure. They conclude that, as the Poisson distribution is applicable to expected values and variances of the same data type, among the observed values it is very common for the variance to be greater than the mean, so that overdispersion is found to exist. For this reason, using the Poisson model for estimation is not appropriate. However, the negative binomial model for the relationship between patents and $R \& D$ expenditure can resolve the problem of overdispersion in the data.

First, let $\tilde{\lambda}_{i t}=\lambda_{i t} \alpha_{i}$, where $\alpha_{i}$ is country $i$ 's fixed effects which do not change over time. As can be seen from the above explanation, $\lambda$ follows a $\operatorname{Gamma}(\gamma, \delta) \quad$ distribution. Therefore, $\quad \tilde{\lambda}_{i t}=\lambda_{i t} \alpha_{i}$ should follow a Gamma $\left(\gamma_{i t}, \frac{\delta_{i}}{\alpha_{i}}\right)$ distribution. Furthermore, let the parameters be as shown in (1), so that we can obtain the estimate $\tilde{\lambda}_{i t}$ and its distribution, as given in (2), where $\phi_{i}$ and $\mu_{i}$ change due to the differences in countries. Given the condition $\sum n_{i t}$, we can derive the conditional probability density function $n_{\mathrm{it}}(\mathrm{t}=1, \ldots, \mathrm{T})$ as shown in (3), where $n_{i t}$ is the number of patents for country $i$ in year $t$. By substituting the definitions $\mathrm{E}\left(n_{i t}\right)=\frac{\gamma_{i t}}{\delta}$ and $\mathrm{V}\left(n_{i t}\right)=\frac{\gamma_{i t}(1+\delta)}{\delta^{2}}$ into (1), we can obtain the variance and mean of the negative binomial fixed effects model, as shown in (4). The variance is larger than the mean, indicating that this model allows for the existence of overdispersion:

$$
\gamma_{i t}=e^{X_{i t} \beta}
$$




$$
\begin{aligned}
& \alpha_{i}=e^{\mu_{i}} \\
& \delta_{i}=\phi_{i} \\
& \tilde{\lambda}_{i t} \sim \operatorname{Gamma}\left(e^{X_{i t} \beta}, \frac{\phi_{i}}{e^{\mu_{i}}}\right) \\
& \operatorname{Pr}\left(\mathrm{n}_{\mathrm{i} 1}, \ldots n_{i T} \mid \sum n_{i t}\right)=\left(\prod_{t} \frac{\Gamma\left(\gamma_{i t}+n_{i t}\right)}{\Gamma\left(\gamma_{i t}\right) \Gamma\left(n_{i t}+1\right)}\right)\left[\frac{\Gamma\left(\sum_{t} \gamma_{i t}\right) \Gamma\left(\sum_{t} n_{i t}+1\right)}{\Gamma\left(\sum_{t} \gamma_{i t}+\sum_{t} n_{i t}\right)}\right] \\
& \mathrm{E}\left(n_{i t}\right)=\frac{\gamma_{i t}}{\delta}=\frac{\left(e^{X_{i t} \beta+\mu_{i}}\right)}{\phi_{i}} \\
& \frac{\mathrm{V}\left(n_{i t}\right)=\frac{\gamma_{i t}(1+\delta)}{\delta^{2}}=\left(\frac{e^{X_{i t} \beta+\mu_{i}}}{\phi_{i}}\right)\left(1+e_{i}^{\mu_{i} / \phi_{i}}\right)}{E\left(n_{i t}\right)}=\frac{\left(e^{\mu_{i}}+\phi_{i}\right)}{\phi_{i}}>1 .
\end{aligned}
$$

The likelihood function is given in (5), and the maximum likelihood approach is used to estimate $\hat{\beta}$ :

$$
\ln L=\sum_{i}\left[\begin{array}{l}
\ln \Gamma\left(\sum_{t} \gamma_{i t}\right)+\ln \Gamma\left(\sum_{t} n_{i t}+1\right)-\Gamma\left(\sum_{t} \gamma_{i t}+\sum_{t} n_{i t}\right) \\
+\sum_{t} \ln \Gamma\left(\gamma_{i t}+n_{i t}\right)-\ln \Gamma\left(\gamma_{i t}\right)-\ln \Gamma\left(n_{i t}+1\right)
\end{array}\right]
$$

\subsection{Negative binomial random effects model}

The derivation of the random effects model is similar to that of the fixed 
effects model. The difference from the fixed effects model lies in $\delta_{i}$ in the random effects model being randomly distributed. Its probability density function can be expressed as $g\left(\delta_{i}\right)$, so that the joint probability density function of $n_{i t}$ and $g\left(\delta_{i}\right)$ is given in (6):

$$
\operatorname{Pr}\left(n_{i t}, \delta_{i}\right)=\operatorname{Pr}\left(n_{i t}\right) \cdot g\left(\delta_{i}\right)
$$

In order to derive the $n_{i t}$ probability density function, it is necessary to integrate the joint probability density function integral to remove $\delta_{i}$. Before integrating, it is necessary to determine the appropriate distribution of $\delta_{i}$. For convenience of estimation, we let $\delta_{i} /\left(1+\delta_{i}\right)=z$, as shown in (7), where $z$ conforms to a Beta $(a, b)$ distribution. Therefore, its probability density function is, as shown in (8). Based on the above, after integration the probability density function can be obtained as shown in (9), and its likelihood function is given in (10). Finally, we use the maximum likelihood approach to estimate $\hat{\beta}$ :

$$
\begin{aligned}
& \delta_{i} /\left(1+\delta_{i}\right)=1 /\left(1+e^{\mu_{i}} / \phi_{i}\right)=z \\
& f(z)=[B(a, b)]^{-1} z^{a-1}(1-z)^{b-1}
\end{aligned}
$$




$$
\begin{gathered}
\operatorname{Pr}\left(n_{i t}\right)=\int_{0}^{1} \prod_{i=1}^{T}\left[\frac{\Gamma\left(\gamma_{i t}+n_{i t}\right)}{\Gamma\left(\gamma_{i t}\right) \Gamma\left(n_{i t}+1\right)} z_{i}^{\gamma_{i t}}\left(1-z_{i}\right)^{n_{i t}}\right] f\left(z_{i}\right) d z_{i} \\
=\frac{\Gamma(a+b) \Gamma\left(a+\sum \gamma_{i t}\right) \Gamma\left(b+\sum n_{i t}\right)}{\Gamma(a) \Gamma(b) \Gamma\left(a+b+\sum \gamma_{i t}+\sum n_{i t}\right)} \prod_{t} \frac{\Gamma\left(\gamma_{i t}+n_{i t}\right)}{\Gamma\left(\gamma_{i t}\right) \Gamma\left(n_{i t}+1\right)} \\
\ln L=\sum_{i}\left\{\begin{array}{l}
\ln \Gamma(a+b)+\ln \left(a+\sum \gamma_{i t}\right)+\ln \Gamma\left(b+\sum y_{i t}\right)-\ln \Gamma(a)-\ln \Gamma(b) \\
-\ln \Gamma\left(a+b+\sum \gamma_{i t}+\sum y_{i t}\right)+\sum_{t}\left[\ln \Gamma\left(\gamma_{i t}+y_{i t}\right)-\ln \Gamma\left(\gamma_{i t}\right)-\ln \Gamma\left(y_{i t}+1\right)\right]
\end{array}\right\}
\end{gathered}
$$

It is worth noting that the fixed effects and random effects models differ in that the random effects model requires that the two parameters $a$ and $b$ be estimated.

The basic model presented in this paper is used to examine the impact of imports, exports, expenditure on technology trade, income from technology trade, domestic R\&D expenditure, and dummy variables on cross-border patents and jointly-invented patents. The empirical model is as shown in (11) and (12), where the dependent variables $\gamma_{i t}$ and $\theta_{i t}$ are Cross patents and Joint patents, respectively, for country $i$ in period $t$.

In order to address the issue of possible endogeneity, we estimate equation (11) using lagged explanatory variables as instruments. However, it has been argued that lagged variables do not always serve as good instruments, and the estimated results may be sensitive to the choice of instruments. Accordingly, we also used other suitable instrumental variables. As lack of data is an issue which prevents use of an instrumental variables, we use lagged variables as instruments: 


$$
\begin{aligned}
& \gamma_{i t}=\exp \left(\begin{array}{l}
\beta_{0}+\beta_{1} \cdot \mathrm{L} 1_{-} \mathrm{Im} \text { port }+\beta_{2} \cdot \mathrm{L} 1_{-} \text {Export }+\beta_{3} \cdot \mathrm{L} 1_{-} T P \\
+\beta_{4} \cdot \mathrm{L} 1_{-} T R+\beta_{5} \cdot \mathrm{L} 1_{-} G E R D+\beta_{6} \cdot O E C D+\varepsilon_{i t}
\end{array}\right) \\
& \theta_{i t}=\exp \left(\begin{array}{l}
\beta_{0}+\beta_{1} \cdot \mathrm{L} 1_{-} \mathrm{Im} \text { port }+\beta_{2} \cdot \mathrm{L} 1 \_ \text {Export }+\beta_{3} \cdot \mathrm{L} 1_{-} T P \\
+\beta_{4} \cdot \mathrm{L} 1_{-} T R+\beta_{5} \cdot \mathrm{L} 1_{-} G E R D+\beta_{6} \cdot \mathrm{L} 1_{-} O E C D+\varepsilon_{i t}
\end{array}\right)
\end{aligned}
$$

In order to lead to more informative empirical results, we divide domestic R\&D expenditure into three kinds of expenditure, namely business enterprise $\mathrm{R} \& \mathrm{D}$ expenditure $(B E R D)$, government agencies' R\&D expenditure (GERD), and higher education R\&D expenditure (HERD). This permits an examination the impacts of these different sectors' $R \& D$ expenditure on patent $s$.

The empirical model is as shown in (13) and (14). The dependent variables $\gamma_{i t}$ and $\theta_{i t}$ are the average numbers of domestically-owned cross-border patents and patents jointly invented in foreign countries, respectively, for country $i$ in year $t$. Of the explanatory variables, L1_Import represents expenditure on imports lagged one period, L1_Export represents expenditure on exports lagged one period, L1_TBP_Payments represents expenditure on technology trade lagged one period, $L 1 \_T B P \_R e c e i p t s$ represents income from technology trade lagged one period, $L 1 \_B E R D$ represents the $\mathrm{R} \& \mathrm{D}$ expenditure of business enterprises lagged one period, L1_GOVERD represents the R\&D expenditure of government agencies lagged one period, and L1_HERD represents the R\&D expenditure of higher education lagged one period, where $\beta$ is the parameter to be estimated: 


$$
\begin{gathered}
\gamma_{i t}=\exp \left(\begin{array}{l}
\beta_{0}+\beta_{1} \cdot \mathrm{L}_{-} \mathrm{Im} \text { port }+\beta_{2} \cdot \mathrm{L} 1_{-} \text {Export }+\beta_{3} \cdot \mathrm{L} 1_{-} T P \\
+\beta_{4} \cdot \mathrm{L} 1_{-} T R+\beta_{5} \cdot \mathrm{L} 1_{-} \mathrm{BERD}+\beta_{6} \cdot \mathrm{L}_{-} \text {GOVERD } \\
+\beta_{7} \cdot \mathrm{L} 1_{-} H R E D+\beta_{8} \cdot \mathrm{OECD}+\varepsilon_{i t}
\end{array}\right) \\
\theta_{i t}=\exp \left(\begin{array}{l}
\beta_{0}+\beta_{1} \cdot \mathrm{L} 1_{-} \mathrm{Im} \text { port }+\beta_{2} \cdot \mathrm{L} 1_{-} \text {Export }+\beta_{3} \cdot \mathrm{L} 1_{-} T P \\
\beta_{4} \cdot \mathrm{L} 1_{-} T R+\beta_{5} \cdot \mathrm{L} 1_{-} B E R D+\beta_{6} \cdot \mathrm{L} 1_{-} G O V E R D \\
+\beta_{7} \cdot \mathrm{L} 1_{-} H E R D+\beta_{8} \cdot O E C D+\varepsilon_{i t}
\end{array}\right)
\end{gathered}
$$

In this paper, we use the STATA statistical software for estimation, where the estimates of the marginal effects are based, for example, on the derivatives of the empirical model (11), namely $\frac{\partial \gamma}{\partial L 1_{-} \text {Import }}=\beta_{1} \gamma^{*}$, where $\gamma^{*}$ is the mean of the dependent variables.

\section{Empirical Results}

The basic model adopted in this paper investigates the impact of imports, exports, technology trade expenditure, revenue from technology trade and domestic $R \& D$ expenditure on patents. In order to avoid the problem of endogeneity, all variables are lagged by one period. In considering $R \& D$ expenditure, it is assumed that a country’s investment in R\&D will not lead to innovation in the current period. Thus, it is necessary to decide on the number of periods by which $R \& D$ expenditure should be deferred.

The correlation coefficients among the dependent and independent variable are given in Table 5. Although they do not appear in the same regression equation, it is not surprising that joint and cross-border patents are highly correlated at 0.995 . None of the 
independent variables is individually highly correlated with either joint or cross-border patents. Among the independent variables, the highest correlations are between Imports and Exports (at 0.987), TR and TP (at 0.864), FDI_in and Exports (at 0.856), and FDI_in and Imports (at 0.850).

\section{$<$ Table 5 goes here $>$}

Tables 6 and 7 report the results of determining the number of periods by which $R \& D$ expenditure should be deferred using the negative binomial model, based on fixed and random effects for cross-border patents and jointly-invented patents. The two models use domestic R\&D expenditure lagged one, two and three periods to examine which specification is better. The criterion on for superiority is based on statistical significance, with greater deemed to be better.

The empirical results show that the use of domestic R\&D expenditure lagged one period is the best for both cross-border (at 0.195 and 0.218 for fixed and random effects, respectively) and joint patents (at 0.176 and 0.201 for fixed and random effects, respectively), indicating that the current domestic $R \& D$ will exhibit the effects of innovation in the following period. It is for this reason that in the following analysis, domestic R\&D expenditure is always lagged one period.

\section{$<$ Tables 6 and 7 go here $>$}

\subsection{Results for cross-border patents}

The model is tested using the Hausman test, with the random effects model as the 
null hypothesis, and the fixed effects model as the alternative hypothesis. The null hypothesis is not rejected. Therefore, cross-border patents in the basic model are explained by random effects, as given in column (2) in Tables 8-10. Cross-border patents refer to the number of patents that are domestically owned but invented by foreign inventors, most of which are the result of cooperation in innovation between domestic enterprises and foreign employees of foreign subsidiary companies. They can reflect the ability to control domestically foreign inventions and inflows of foreign technology from abroad.

\section{< Tables 8-10 go here >}

In what follows, we analyze the basic model for which cross-border patent is the dependent explanatory variable:

(a) L1_Import that are traded internationally have a negative impact on cross-border patents at the 1\% level of significance. L1_Export have no significant impact on cross-border patents. Thus, international trade has virtually no significant impact on innovation cooperation, with exports having no impact and imports hindering cross-border innovation cooperation. As most of the countries comprising the sample are high income and highly developed countries, most of the domestic enterprises are engaged in technology-intensive industries, and the knowledge or technology that can be learned through imports is limited. On the other hand, contact is made with foreign enterprises through exports, and in competition with them, cooperation in innovation is not enhanced. It can be seen that the impact of 
imports hindering innovation cooperation is greater than the zero impact of exports.

(b) Technology trade ( $L 1 \_T P$ and $L 1 \_T R$ ), which consists of directly exchanging knowledge and technology through licensing or purchases and sales between countries, is an important indicator to measure technology diffusion. The expenditure on technology trade and the income from technology trade, with each variable lagged one period, are positively and negatively correlated with patents, respectively, at the $1 \%$ level of significance. The volume of technology trade reflects the flows of technology, where greater expenditure on technology means the domestic country is more heavily engaged in investing in technology internationally, so that innovation cooperation will be encouraged. On the contrary, the larger is the income from technology trade, the more will countries accept the commissioning of invention work abroad. For this reason, there is a negative relationship with cross-border patents. However, regardless of whether they arise from income from technology trade or expenditure on technology trade, flows of technology are always seen to exist. The coefficient of expenditure on technology trade is 0.287 , while that for income from technology trade is -0.447 , with the magnitude of the positive effect on innovation being smaller than the negative effect.

(c) The impact of inward foreign direct investment on cross-border patents is significant, at -0.475 and -0.508 for fixed and random effects, respectively (see Table 8).

(d) The impact of outward foreign direct investment on cross-border patents is 
not significant.

(e) L1_GERD is positively correlated with patents at the $1 \%$ level of significance. This variable measures the country's investment in R\&D, and indicates whether investment in domestic R\&D promotes innovation cooperation, and if the effect of the country's investment in domestic R\&D will be observed in the next period.

(f) The dummy variables that indicate a country's membership in the OECD are not significant.

\subsection{Results for jointly-invented patent}

The Hausman test rejects the null hypothesis of random effects, so that jointly-invented patents under the basic model are explained by fixed effects, as given in column (3) in Tables 8-10. Jointly-invented patents refer to the patents for which domestic inventors have cooperated jointly with at least one foreign inventor. As another approach to investigate patent cooperation, in what follows we analyze the basic model in which patents that are invented jointly with foreign countries are given as the dependent variable:

(a) L1_Import and L1_Export have no significant effects on joint patents. As the sample of countries consists of mostly high income and advanced countries in terms of economic development, the products imported by such countries are primarily low technology-intensive products. When faced with countries with relatively low technology, the incentive to engage in innovation cooperation is comparatively small .

(b) Technology trade ( $L 1_{-} T P$ and $L 1 \_T R$ ) exhibit positive and negative relationships, 
respectively, with innovation cooperation at the $10 \%$ and $1 \%$ levels of significance. Expenditure on technology trade denotes the extent to which the country domestically uses foreign technology, so that innovation cooperation exchanges between domestic and foreign research personnel are more frequent. In such circumstances, technology is disseminated internationally, but the income from technology trade leads to a significant reduction in innovation cooperation. The greater is the income from technology trade, the greater is the degree of domestic innovation, so there is a tendency for foreign countries to purchase the domestic country's technology. For this reason, in the case of research personnel in countries owning a relatively large amount of technology, there is relatively little incentive for them to engage in innovation cooperation with foreign research personnel. The coefficient of expenditure on technology trade is 0.156 , and the coefficient for income from foreign trade is -0.279 . This also shows that the magnitude of the positive impact on innovation is smaller than that of the negative impact.

(c) The impact of inward foreign direct investment on joint patents is marginally significant (at -0.352 for random effects) (see Table 8 ).

(d) The impact of outward foreign direct investment on joint patents is not significant.

(e) L1_GERD exhibits a positive relationship with innovation cooperation at the $1 \%$ level of significance. In order to promote innovation cooperation, it is necessary to promote investment by the domestic country in $R \& D$, and the effect of investment in the current period will be felt in the following period.

(f) The dummy variables, indicating whether a country is a member of the OECD and engages in innovation cooperation, are not significant. 
Based on the above, cross-border patents are relatively more significantly influenced by foreign trade and technology trade. Both cross-border patents and jointly-invented patents are affected by domestic $R \& D$ expenditure, resulting in technology diffusion and an increase in innovation activities. For this reason, in the next section we decompose R\&D expenditure by sector, and discuss the respective impacts of R\&D expenditure of different sectors on innovation cooperation and innovation activities.

\subsection{Decomposition of $R \& D$ for Cross-border patents}

Tables 11-13 present the estimation results for the model in which $R \& D$ is decomposed. This model decomposes domestic $R \& D$ expenditure into corporate $R \& D$ expenditure, government department $\mathrm{R} \& \mathrm{D}$ expenditure, and higher education $\mathrm{R} \& \mathrm{D}$ expenditure, and each of the variables is lagged one period. In Tables 11-13, the dependent variables in columns (1) and (2) are cross-border patents, and those in (3) and (4) are jointly-invented patents, though the discussion concentrates on cross-border patents. Equations (1) and (3) use the fixed effects model, while equations (2) and (4) use the random effects model.

The Hausman test does not reject the null hypothesis, so that the random effects model is used to describe the cross-border patents based on $\mathrm{R} \& \mathrm{D}$ expenditures decomposed by sector, as shown in Tables 11-13 (column 2). The assessment is given as follows:

(a) Corporate $R \& D$ expenditure and higher education R\&D expenditure, each lagged one period, exhibit positive impacts on patents at the $5 \%$ significance level, while government $R \& D$ expenditure lagged one period has no impact on cross-border 
patents. As cross-border patents are essentially the result of innovation cooperation between the research personnel of domestic enterprises and of foreign subsidiaries, domestic R\&D expenditure is affected by the enterprises' corporate R\&D expenditure. The more that an enterprise invests in $R \& D$, the more it can learn about what it lacks. For this reason, through the foreign inventor's ability to innovate, the domestic country's technology can be encouraged to grow, and technology will flow to the domestic economy from abroad.

(b) Investment by countries in human capital is also important as enterprises that need highly-skilled talent in technology and knowledge have the ability to cooperate in innovating with foreign researchers. The coefficient for higher education $R \& D$ expenditure of 0.775 for random effects, and for corporate $R \& D$ expenditure is 0.175 for random effects, indicating that the positive impact of the higher education on innovation cooperation is greater than the positive impact of corporate $R \& D$ expenditure.

(c) It is interesting to note that government expenditure on R\&D is not significant, whereas government expenditure on higher education is significant. It would seem to be important for governments to spend more on higher education than on its own R\&D.

\subsection{The jointly-invented paten ts effect of $R \& D$}

The Hausman test does not reject the null hypothesis, so that jointly-invented patents may be explained using random effects based on the R\&D model decomposed by sector, as shown in Tables 11-13 (column4). In what follows, the jointly invented patents with a foreign country will serve as the explanatory variable in the R\&D model 
decomposed by sector. The estimated results of the analysis are given as follows:

(a) Corporate $R \& D$ expenditure lagged one period and government agency $R \& D$ expenditure are both insignificant, with higher education $R \& D$ expenditure exhibiting a positive impact on joint patents at the $1 \%$ level. Thus, when an inventor in the domestic country engages in innovation cooperation with a foreign inventor, expenditure on $R \& D$ will tend to be more concentrated in expenditure on $R \& D$ in higher education, reflecting the importance of education in human resources.

(b) As Mancusi (2008) observed, the extent to which knowledge and technology can be used depends on the ability to understand and interpret such knowledge and technology. In order to increase cooperation in innovation between foreign and domestic research personnel, it is necessary to raise the level of knowledge in the domestic country. It is important to note that government expenditure on higher education is highly significant, so that governments should continue to spend more on higher education than on its own R\&D.

\section{Conclusion}

This paper used panel data for 40 countries for 1981-2008 and the negative binomial model for empirical estimation. We examined the diffusion of technology between countries through innovation cooperation and the extent of a country’s innovation. A basic model was used to examine the impact of imports, exports, expenditure on and income from technology trade, and expenditure on domestic R\&D on innovation cooperation, and the extent of a country's 
innovation. We also examined a country's domestic R\&D and expenditure decomposed into three sectors, namely corporate $R \& D$ expenditure, government agencies’ R\&D expenditure, and higher education R\&D expenditure.

Each of the explanatory variables was based on the period before the joint and cross-border patents were observed. Patent cooperation was used as a proxy variable for technology diffusion, where the analysis of patent cooperation proceeded with two novel types of variables for patents, namely cross-border patents and jointly-invented patents. As these patents differ from each other, by definition, the directions of their technology diffusion can also differ.

In what follows, we define the novel data used for their kinds of patent cooperation used in the paper. As the countries of residence of the patent owner and the inventor of the patent are described in detail in the patent document, we can track the direction of the flow of technology. The cross-border patent is defined as a patent by an inventor in a foreign country and owned domestically, indicating that the patent owner is in the local country and the inventor in a foreign country. It can be inferred that the direction of the flow of the technology is from the foreign country to the domestic country. A jointly-invented patent is defined as a patent where an inventor in the local country invents the patent jointly with at least one foreign inventor. It can be inferred that the direction of the flow of the technology is in both directions. For this reason, depending on the direction of the flow of technology, in accordance with the empirical results obtained we have the following conclusions:

\section{(a) Technology flows from the foreign country to the domestic country:}


1. Expenditure on technology trade in the previous period each promote inflows of technology into the domestic country from abroad. However, imports and income from technology trade in the previous period tend to hinder inflows of foreign technology from abroad. Inward foreign direct investment also has a negative impact on cross-border patents.

2. If a country wants technology to flow into the domestic economy from abroad, the local economy should increase its investment in corporate R\&D and higher education $R \& D$. If an enterprise pays considerable attention to innovative development, it is bound to promote innovation by the employees of its subsidiaries, which will then cause foreign knowledge to flow into the domestic economy. Consequently, the domestic enterprises will gain from innovation, and this outcome will generally occur one period after the investment in R\&D occurs.

\section{(b) Technology flows in both directions:}

1. Expenditure on technology trade lagged one period will promote the bilateral diffusion of technology. However, imports lagged one period and income from technology trade lagged one period will hinder the bilateral diffusion of technology. Inward foreign direct investment also has a negative impact on joint patents.

2. In order to promote the bilateral diffusion of technology, investment in higher education R\&D should be bolstered because cooperation requires incentives. The domestic country's research personnel need to reach a certain level of knowledge if they are to entice foreign inventors to engage in 
innovative cooperation with their own inventors to achieve a mutually beneficial outcome.

3. Government expenditure on higher education is highly significant, so governments should continue to spend more on higher education than on its own R\&D.

Finally, based on the above, the following recommendations are offered for future research, and for countries to formulate policies to promote the development of technology:

(a) Patents can serve as a proxy variable for innovation, and different types of patents can be used in research. According to the different definitions of patents and the ways in which innovation activities are conducted, different types of results can be analyzed. Cross-border patents can be used to analyze the inflow of foreign technology into a country, while jointly-invented patents can be used to analyze bilateral flows of technology.

(b) In terms of public and private policy, countries should focus on investment in higher education research and on foreign technology trade. Regardless of whether it is knowledge or technology, both are created by inventors, and the positive external effects caused by inflows of technology will depend on a country's ability to understand knowledge and technology.

(c) Income from technology trade will promote a country's engagement in innovation, while expenditure on technology trade will promote innovation cooperation between the domestic country and foreign countries. In short, the more frequent are the flows of technology, the greater will that innovative behavior be encouraged within the home country. 
In summary, if it is desired to shift from foreign to domestic technology, it is necessary to increase expenditure on $R \& D$ for business enterprises and higher education, exports and technology. If the focus is on increasing bilateral technology diffusion, it is necessary to increase expenditure on $R \& D$ for higher education and technology. It is also found that outward direct investment has no significant impact on either joint or cross-border patents, whereas inward foreign direct investment has a significant negative impact on cross-border patents but no impact on joint patents. As government expenditure on higher education is highly significant, governments should continue to spend more on higher education than on its own R\&D. 


\section{References}

Branstetter, L.G. (2001), “Are Knowledge Spillovers International or Intranational in Scope? Microeconometric Evidence from the U.S. and Japan”, Journal of International Economics, 53(1), pp. 53-79.

Carr, D.L., Markusen, J.R. and K.E. Maskus (2001), “Estimating the Knowledge-Capital Model of the Multinational Enterprise”, American Economic Review, 91(3), pp. 693-708.

Cassia, L. and A. Colombelli (2008), “Do universities knowledge spillovers impact on new firm's growth? Empirical evidence from UK”, International Entrepreneurship and Management Journal, 4(4), pp. 453-465.

Chang, C.-L., and S. Robin (2006), “Doing R\&D and/or Importing Technologies: The Critical Importance of Firm Size in Taiwan's Manufacturing Industries”, Review of Industrial Organization, 29(3), pp. 253-278.

Chang, C.-L., and S. Robin (2012), "Knowledge Sourcing and Firm Performance in an Industrializing Economy: The Case of Taiwan (1992-2003)”, Empirical Economics, 42(3), pp. 947-986.

Chang, C.-L., S.-P. Chen and M. McAleer (2013), “Globalization and Knowledge Spillover: International Direct Investment, Exports and Patents”, Economics of Innovation and New Technology, 22(4), pp. 329-352.

Clerides, S.K., Lach, S. and J. R. Tybout (1998), “Is learning by Exporting Important? Micro-dynamic Evidence from Colombia, Mexico, and Morocco”, Quarterly Journal of Economics, 113(3), pp. 903-947.

Coe, D.T. and E. Helpman (1995), “International R\&D Spillovers”, European Economic Review, 39(5), pp. 859-887.

Coe, D.T., E. Helpman, and A.W. Hoffmaister (1997), “North-South R\&D Spillovers”, Economic Journal, 107(440), pp.134-149.

Coe, D. T., E. Helpman, and A.W. Hoffmaister (2008), “International R\&D Spillovers and institutions”, NBER Working Paper 14069.

Cohen, W.M. and D.A. Levinthal (1989), "Innovation and Learning: the Two Faces of R\&D”, Economic Journal, 99(397), pp. 569-596.

Eaton, J. and S. Kortum (1996), “Trade in ideas Patenting and Productivity in the 
OECD ”, Journal of International Economics, 40(3-4), pp. 251-278.

García, F., B. Jin, and R. Salomon (2013), “Does Inward Foreign Direct Investment Improve the Innovative Performance of Local Firms?, Research Policy, 42(1), pp. 231-244.

Geroski, P., S. Machin, and J. Van Reenen (1993), “The Profitability of Innovating Firms”, RAND Journal of Economics, 24(2), pp. 198-211.

Hagedoorn, J. and N. Wang (2012), “Is There Complementarity or Substitutability Between Internal and External R\&D Strategies?”, Research Policy, 41(6), pp. 1072-1083.

Hausman, J. A., B.H. Hall, and Z. Griliches (1984), "Econometric Models for Count Data with an Application to the Patents-R\&D Relationship”, Econometrica, 52(4), pp. 909-938.

Lee, G. (2006), “The Effictiveness of Intermational Knowledge Spillover Channels”, European Economic Review, 50(8), pp. 2075-2088.

Lichtenberg, F. and B. van Pottesberghe de la Potterie (1998), "International R\&D Spillover: A Re-examination”, European Economic Review, 42(8), pp. 1483-1491.

Keller, W. (1998), “Are international R\&D Spillovers Trade-Related? Analyzing Spillovers Among Randomly Matched Trade Partners”, European Economic Review, 42(8), pp. 1469-1481.

Keller, W. (2000), “Do Trade Patterns and Technology Flows Affect Productivity Growth?”, The World Bank Economic Review, 14(1), pp. 17-47.

Keller, W. (2001), “International Technology Diffusion”, NBER Working Paper 8573.

Madsen, J.B. (2007), “Technology Spillover Through Trade and TFP Convergence: 135 Years of Evidence for the OECD Countries”, Journal of International Economics, 72(2), pp. 464-480.

Mancusi, M.L. (2008), “International Spillovers and Absorptive Capacity: A Cross-country Cross-sector Analysis Based on Patents and Citations”, Journal of International Economics, 76(2), pp. 155-165.

Norman, G. and L. Pepall (2004), “Knowledge Spillovers, Mergers and Public Policy in Economic Clusters”, Review of Industrial Organization, 25(2), pp. 155-174. 
OECD. (1996), The Knowledge-Based Economy, OECD.

OECD. (2008), Compendium of Patent Statistics, OECD.

OECD .(2010), Main Science and Technology Indicators, OECD.

Xu, B. and J. Wang (1999), “Capital Goods Trade and R\&D Spillovers in the OECD”, Canadian Journal of Economics, 32(5), pp. 1258-1274.

Woerter, M and S. Roper (2010), “Openness and Innovation-Home and Export Demand Effects on Manufacturing Innovation: Panel Data Evidence for Ireland and Switzerland”, Research Policy, 39(1), pp. 155-164. 
Table 1. Countries

\begin{tabular}{|c|c|c|c|c|}
\hline & \multicolumn{2}{|c|}{ OECD member countries } & \multirow{2}{*}{$\begin{array}{c}\text { Non-OECD } \\
\text { member } \\
\text { countries }\end{array}$} & \multirow[t]{2}{*}{ Total } \\
\hline & $\begin{array}{l}\text { Original Members in } \\
\qquad 1961\end{array}$ & $\begin{array}{c}\text { Members after } \\
1961\end{array}$ & & \\
\hline Asia & Turkey & $\begin{array}{c}\text { Japan (1964), } \\
\text { Korea (1996), } \\
\text { Israel (2010) }\end{array}$ & $\begin{array}{c}\text { China, Russia, } \\
\text { Singapore, } \\
\text { Taiwan }\end{array}$ & 8 \\
\hline Europe & $\begin{array}{l}\text { Austria, Belgium, } \\
\text { Denmark, France, Germany, } \\
\text { Greece, Iceland, Ireland, Italy, } \\
\text { Luxembourg, Netherlands, } \\
\text { Norway, Portugal, Spain, } \\
\text { Sweden, Switzerland, Britain }\end{array}$ & $\begin{array}{c}\text { Finland (1969), } \\
\text { Poland (1996), } \\
\text { Slovakia 2000), } \\
\text { Slovenia (2010), } \\
\text { Czech Republic } \\
\text { (1995), Hungary } \\
\text { (1996) }\end{array}$ & Romania & 25 \\
\hline Oceania & & $\begin{array}{c}\text { Australia (1971) } \\
\text { New Zealand } \\
\text { (1973) }\end{array}$ & & 1 \\
\hline America & Canada, United States & $\begin{array}{l}\text { Chile (2010), } \\
\text { Mexico (1994) }\end{array}$ & Argentina & 5 \\
\hline Africa & & & South Africa & 1 \\
\hline Total & 20 & 13 & 7 & 40 \\
\hline
\end{tabular}

Source: OECD

Note : () is the entry date of countries to the OECD. 
Table 2. Variables

\begin{tabular}{|c|c|}
\hline \multicolumn{2}{|c|}{ Dependent Variable } \\
\hline $\begin{array}{l}\text { Cross-border } \\
\text { Patent }\end{array}$ & $\begin{array}{l}\text { The number of patents owned by the home country that } \\
\text { were invented by foreign inventors }\end{array}$ \\
\hline Joint Patent & $\begin{array}{l}\text { The number of patents in which the domestic inventor } \\
\text { invented the patent with at least one foreign inventor }\end{array}$ \\
\hline \multicolumn{2}{|c|}{ Explanatory Variables } \\
\hline Import & Imports divided by GDP \\
\hline Export & Exports divided by GDP \\
\hline FDI_in & Inward Foreign Direct Investment divided by GDP \\
\hline FDI_out & Outward Foreign Direct Investment divided by GDP \\
\hline$T P$ & Expenditure on technology trade divided by GERD \\
\hline$T R$ & Income from technology trade divided by GERD \\
\hline GERD & Gross domestic expenditure on R\&D divided by GDP (\%) \\
\hline$B E R D$ & $\begin{array}{l}\text { Business enterprise expenditure on R\&D divided by GDP } \\
(\%)\end{array}$ \\
\hline GOVERD & $\begin{array}{l}\text { Government intramural expenditure on R\&D divided by } \\
\text { GDP (\%) }\end{array}$ \\
\hline$H E R D$ & Higher education expenditure on R\&D divided by GDP (\%) \\
\hline$O E C D$ & Dummy variable (OECD $=1$ for OECD members) \\
\hline \multicolumn{2}{|r|}{ Notes } \\
\hline$L 1, L 2, L 3$ & 1-year, 2-year and 3-year time lags \\
\hline
\end{tabular}


Table 3. Summary Statistics

\begin{tabular}{lccccc}
\hline \hline Variables & Mean & $\begin{array}{c}\text { Standard } \\
\text { error }\end{array}$ & Min & Max & $\begin{array}{c}\text { Sample } \\
\text { size }\end{array}$ \\
\hline $\begin{array}{l}\text { Cross-border } \\
\text { Patents }\end{array}$ & 3144.242 & 12279.97 & 0 & 114746 & 1120 \\
\hline Joint & 3255.079 & 12171.3 & 0 & 114333 & 1120 \\
Patents & 0.3912 & 0.2928 & 0.0463 & 2.1249 & 1070 \\
Import & 0.4057 & 0.3265 & 0.0660 & 2.3435 & 1070 \\
Export & 0.5702 & 1.1649 & 0.0062 & 11.1008 & 577 \\
TP & 0.4258 & 1.2219 & 0.0011 & 13.7397 & 574 \\
TR & 0.2544 & 0.3018 & 0 & 1.8826 & 1016 \\
FDI_in & 0.1845 & 0.2514 & 0.0003 & 2.0009 & 1005 \\
FDI_out & 0.0160 & 0.0088 & 0.0015 & 0.0483 & 799 \\
GERD & 0.0025 & 0.0012 & 0.0002 & 0.0075 & 782 \\
GOVERD & 0.0098 & 0.0070 & 0.0001 & 0.0390 & 792 \\
BERD & 0.0033 & 0.0018 & 0.00004 & 0.0084 & 781 \\
HERD & & & & & \\
\hline \hline
\end{tabular}

Table 4. Zero Observations

\begin{tabular}{c|c|c}
\hline & Cross- border patents & Joint patents \\
\hline Zero values & 35 & 24 \\
\hline Observations & 1,120 & 1,120 \\
\hline Share of zeros & 0.031 & 0.021 \\
\hline \hline
\end{tabular}


Table 5. Correlation Coefficients

\begin{tabular}{|c|c|c|c|c|c|c|c|c|c|}
\hline $\begin{array}{c}\text { Dependent } \\
\text { Variable }\end{array}$ & Joint & Cross-border & Imports & Exports & $T P$ & $T R$ & FDI_in & FDI_out & GERD \\
\hline Joint & 1 & & & & & & & & \\
\hline Cross-border & 0.995 & 1 & & & & & & & \\
\hline \multicolumn{10}{|l|}{$\begin{array}{c}\text { Independent } \\
\text { Variable } \\
\end{array}$} \\
\hline Imports & -0.285 & -0.281 & 1 & & & & & & \\
\hline Exports & -0.278 & -0.275 & 0.987 & 1 & & & & & \\
\hline$T P$ & -0.158 & -0.155 & 0.549 & 0.555 & 1 & & & & \\
\hline$T R$ & -0.081 & -0.081 & 0.262 & 0.286 & 0.864 & 1 & & & \\
\hline FDI_in & -0.163 & -0.161 & 0.850 & 0.856 & 0.582 & 0.378 & 1 & & \\
\hline FDI_out & -0.053 & -0.057 & 0.578 & 0.621 & 0.377 & 0.369 & 0.775 & 1 & \\
\hline$G E R D$ & 0.398 & 0.394 & -0.056 & -0.0002 & -0.130 & 0.014 & -0.014 & 0.294 & 1 \\
\hline
\end{tabular}


Table 6. Lag Structure of R\&D for Cross-border Patents

\begin{tabular}{|c|c|c|c|c|c|c|}
\hline \multirow[b]{3}{*}{ Variable } & \multicolumn{6}{|c|}{ Cross-border patents } \\
\hline & \multicolumn{3}{|c|}{ Fixed Effects } & \multicolumn{3}{|c|}{ Random Effects } \\
\hline & (1) & (3) & (5) & $(2)$ & (4) & (6) \\
\hline$L 1 \_T P$ & $\begin{array}{c}0.240 \\
(0.098)^{* *}\end{array}$ & $\begin{array}{c}0.173 \\
(0.108)\end{array}$ & $\begin{array}{c}0.242 \\
(0.101)^{* *}\end{array}$ & $\begin{array}{c}0.241 \\
(0.098)^{* *}\end{array}$ & $\begin{array}{c}0.168 \\
(0.107)\end{array}$ & $\begin{array}{c}0.237 \\
(0.101)^{* *}\end{array}$ \\
\hline$L 1 \_T R$ & $\begin{array}{c}-0.369 \\
(0.117)^{* * *}\end{array}$ & $\begin{array}{c}-0.319 \\
(0.126)^{* *}\end{array}$ & $\begin{array}{c}-0.378 \\
(0.123)^{* * *}\end{array}$ & $\begin{array}{c}-0.346 \\
(0.114)^{* * *}\end{array}$ & $\begin{array}{c}-0.287 \\
(0.121)^{* *}\end{array}$ & $\begin{array}{c}-0.348 \\
(0.119)^{* * *}\end{array}$ \\
\hline FDI_in & $\begin{array}{c}-0.475 \\
(0.207)^{* *}\end{array}$ & $\begin{array}{l}-0.332 \\
(0.222)\end{array}$ & $\begin{array}{c}-0.551 \\
(0.222)^{* *}\end{array}$ & $\begin{array}{c}-0.508 \\
(0.206)^{* *}\end{array}$ & $\begin{array}{l}-0.356 \\
(0.221)\end{array}$ & $\begin{array}{c}-0.576 \\
(0.221)^{* * *}\end{array}$ \\
\hline FDI_out & $\begin{array}{c}0.142 \\
(0.184)\end{array}$ & $\begin{array}{l}-0.031 \\
(0.209)\end{array}$ & $\begin{array}{c}0.047 \\
(0.199)\end{array}$ & $\begin{array}{c}0.141 \\
(0.181)\end{array}$ & $\begin{array}{l}-0.039 \\
(0.206)\end{array}$ & $\begin{array}{c}0.040 \\
(0.197)\end{array}$ \\
\hline L1_GERD & $\begin{array}{c}0.195 \\
(0.055)^{* * *}\end{array}$ & & & $\begin{array}{c}0.218 \\
(0.054)^{* * *}\end{array}$ & & \\
\hline L2_GERD & & $\begin{array}{c}0.131 \\
(0.061)^{* *}\end{array}$ & & & $\begin{array}{c}0.156 \\
(0.060)^{* * *}\end{array}$ & \\
\hline L3_GERD & & & $\begin{array}{c}0.156 \\
(0.060)^{* * *}\end{array}$ & & & $\begin{array}{c}0.179 \\
(0.059)^{* * *}\end{array}$ \\
\hline$O E C D$ & $\begin{array}{c}0.037 \\
(0.188)\end{array}$ & $\begin{array}{l}-0.092 \\
(0.200)\end{array}$ & $\begin{array}{l}-0.116 \\
(0.204)\end{array}$ & $\begin{array}{c}0.098 \\
(0.185)\end{array}$ & $\begin{array}{l}-0.013 \\
(0.198)\end{array}$ & $\begin{array}{l}-0.032 \\
(0.202)\end{array}$ \\
\hline Constant & $\begin{array}{c}1.149 \\
(0.197)^{* * *}\end{array}$ & $\begin{array}{c}1.443 \\
(0.210)^{* * *}\end{array}$ & $\begin{array}{c}1.436 \\
(0.214)^{* * *}\end{array}$ & $\begin{array}{c}1.054 \\
(0.197)^{* * *}\end{array}$ & $\begin{array}{c}1.326 \\
(0.211)^{* * *}\end{array}$ & $\begin{array}{c}1.318 \\
(0.215)^{* * *}\end{array}$ \\
\hline $\begin{array}{l}\text { Log } \\
\text { likelihood }\end{array}$ & -3361.32 & -2885.15 & -3008.90 & -3735.62 & -3238.27 & -3368.18 \\
\hline Wald chi2 & 27.57 & 20.46 & 29.68 & 30.56 & 20.92 & 30.16 \\
\hline Prob > chi2 & 0.000 & 0.002 & 0.000 & 0.000 & 0.002 & 0.000 \\
\hline Observations & 534 & 460 & 480 & 534 & 460 & 480 \\
\hline
\end{tabular}

Note: Standard errors are given in parentheses. $* * *, * *$ and $*$ denote significance at the $1 \%, 5 \%$ and $10 \%$ levels, respectively. 
Table 7. Lag Structure of R\&D for Joint Patents

\begin{tabular}{|c|c|c|c|c|c|c|}
\hline \multirow[b]{3}{*}{ Variable } & \multicolumn{6}{|c|}{ Joint patents } \\
\hline & \multicolumn{3}{|c|}{ Fixed Effects } & \multicolumn{3}{|c|}{ Random Effects } \\
\hline & (1) & (3) & (5) & $(2)$ & (4) & (6) \\
\hline$L 1 \_T P$ & $\begin{array}{c}0.146 \\
(0.086) \\
*\end{array}$ & $\begin{array}{c}0.077 \\
(0.092)\end{array}$ & $\begin{array}{c}0.156 \\
(0.087)^{*}\end{array}$ & $\begin{array}{c}0.149 \\
(0.086 \\
)^{*}\end{array}$ & $\begin{array}{c}0.078 \\
(0.092)\end{array}$ & $\begin{array}{c}0.156 \\
(0.087) *\end{array}$ \\
\hline$L 1 \_T R$ & $\begin{array}{c}-0.216 \\
(0.096) \\
* *\end{array}$ & $\begin{array}{l}-0.156 \\
(0.098)\end{array}$ & $\begin{array}{c}-0.225 \\
(0.100)^{* *}\end{array}$ & $\begin{array}{c}-0.206 \\
(0.092 \\
)^{* *}\end{array}$ & $\begin{array}{c}-0.143 \\
(0.094)\end{array}$ & $\begin{array}{c}-0.221 \\
(0.096)^{* *}\end{array}$ \\
\hline L1_FDI_in & $\begin{array}{c}-0.302 \\
(0.212)\end{array}$ & $\begin{array}{l}-0.126 \\
(0.227)\end{array}$ & $\begin{array}{c}-0.341 \\
(0.222)\end{array}$ & $\begin{array}{c}-0.352 \\
(0.209 \\
)^{*}\end{array}$ & $\begin{array}{l}-0.170 \\
(0.225)\end{array}$ & $\begin{array}{c}-0.383 \\
(0.220)^{*}\end{array}$ \\
\hline L1_FDI_out & $\begin{array}{l}-0.029 \\
(0.198)\end{array}$ & $\begin{array}{c}-0.216 \\
(0.224)\end{array}$ & $\begin{array}{c}-0.117 \\
(0.213)\end{array}$ & $\begin{array}{c}-0.009 \\
(0.193 \\
)\end{array}$ & $\begin{array}{l}-0.198 \\
(0.218)\end{array}$ & $\begin{array}{c}-0.103 \\
(0.208)\end{array}$ \\
\hline L1_GERD & $\begin{array}{c}0.176 \\
(0.052) \\
* * *\end{array}$ & & & $\begin{array}{c}0.201 \\
(0.051 \\
)^{* * *}\end{array}$ & & \\
\hline L2_GERD & & $\begin{array}{c}0.113 \\
(0.057)^{* *}\end{array}$ & & & $\begin{array}{c}0.140 \\
(0.056)^{* *}\end{array}$ & \\
\hline L3_GERD & & & $\begin{array}{c}0.117 \\
(0.056)^{* *}\end{array}$ & & & $\begin{array}{c}0.143 \\
(0.555)^{* *}\end{array}$ \\
\hline$O E C D$ & $\begin{array}{l}-0.059 \\
(0.174)\end{array}$ & $\begin{array}{c}-0.169 \\
(0.181)\end{array}$ & $\begin{array}{c}-0.168 \\
(0.184)\end{array}$ & $\begin{array}{c}-0.001 \\
(0.170 \\
)\end{array}$ & $\begin{array}{c}-0.096 \\
(0.177)\end{array}$ & $\begin{array}{c}-0.089 \\
(0.181)\end{array}$ \\
\hline Constant & $\begin{array}{c}1.431 \\
(0.186) \\
* * *\end{array}$ & $\begin{array}{c}1.613 \\
(0.195)^{* *} \\
*\end{array}$ & $\begin{array}{c}1.618 \\
(0.199)^{* * *}\end{array}$ & $\begin{array}{c}1.250 \\
(0.184 \\
)^{* * *}\end{array}$ & $\begin{array}{c}1.505 \\
(0.194)^{* *} \\
*\end{array}$ & $\begin{array}{c}1.505 \\
(0.197)^{* *} \\
*\end{array}$ \\
\hline $\begin{array}{l}\text { Log- } \\
\text { likelihood }\end{array}$ & $\begin{array}{c}-3529 \\
44\end{array}$ & -3035.23 & -3163.72 & $\begin{array}{c}-3913 . \\
27\end{array}$ & -3398.20 & -3533.41 \\
\hline Wald chi2 & & 14.78 & 21.04 & & 15.93 & 22.06 \\
\hline Prob $>$ chi 2 & $\begin{array}{l}19.83 \\
0.003 \\
\end{array}$ & 0.022 & 0.002 & $\begin{array}{l}23.40 \\
0.000\end{array}$ & 0.014 & 0.001 \\
\hline Observations & 534 & 460 & 480 & 534 & 460 & 480 \\
\hline
\end{tabular}

Note: Standard errors are given in parentheses. ${ }^{* * *},{ }^{* *}$ and $*$ denote significance at the $1 \%, 5 \%$ and $10 \%$ levels, respectively. 
Table 8. Effects of Cross-border Patents and Joint Patents (under GERD)

\begin{tabular}{|c|c|c|c|c|}
\hline \multirow[b]{2}{*}{ Variable } & \multicolumn{2}{|c|}{ Cross-border Patents } & \multicolumn{2}{|c|}{ Joint Patents } \\
\hline & $\begin{array}{l}\text { Fixed } \\
\text { Effects } \\
(1)\end{array}$ & $\begin{array}{c}\text { Random } \\
\text { Effects } \\
(2)\end{array}$ & $\begin{array}{c}\text { Fixed } \\
\text { Effects } \\
(3)\end{array}$ & $\begin{array}{c}\text { Random } \\
\text { Effects } \\
(4)\end{array}$ \\
\hline \multicolumn{5}{|l|}{ L1_Import } \\
\hline \multicolumn{5}{|l|}{ L1_Export } \\
\hline L1_TP & $\begin{array}{c}0.240 \\
(0.098)^{* *}\end{array}$ & $\begin{array}{c}0.241 \\
(0.098)^{* *}\end{array}$ & $\begin{array}{c}0.146 \\
(0.086)^{*}\end{array}$ & $\begin{array}{c}0.149 \\
(0.086)^{*}\end{array}$ \\
\hline$L 1 \_T R$ & $\begin{array}{c}-0.369 \\
(0.117)^{* * *}\end{array}$ & $\begin{array}{c}-0.346 \\
(0.114)^{* * *}\end{array}$ & $\begin{array}{c}-0.216 \\
(0.096)^{* *}\end{array}$ & $\begin{array}{c}-0.206 \\
(0.092)^{* * *}\end{array}$ \\
\hline L1_FDI_in & $\begin{array}{c}-0.475 \\
(0.207)^{* *}\end{array}$ & $\begin{array}{c}-0.508 \\
(0.206)^{* *}\end{array}$ & $\begin{array}{l}-0.302 \\
(0.212)\end{array}$ & $\begin{array}{c}-0.352 \\
(0.209)^{*}\end{array}$ \\
\hline L1_FDI_out & $\begin{array}{c}0.142 \\
(0.184)\end{array}$ & $\begin{array}{c}0.141 \\
(0.181)\end{array}$ & $\begin{array}{l}-0.029 \\
(0.198)\end{array}$ & $\begin{array}{c}-0.009 \\
(0.193)\end{array}$ \\
\hline L1_GERD & $\begin{array}{c}0.195 \\
(0.055)^{* * *}\end{array}$ & $\begin{array}{c}0.218 \\
(0.054)^{* * *}\end{array}$ & $\begin{array}{c}0.173 \\
(0.052)^{* * *}\end{array}$ & $\begin{array}{c}0.201 \\
(0.051)^{* * *}\end{array}$ \\
\hline$O E C D$ & $\begin{array}{c}0.037 \\
(0.188)\end{array}$ & $\begin{array}{c}0.098 \\
(0.185)\end{array}$ & $\begin{array}{l}-0.059 \\
(0.174)\end{array}$ & $\begin{array}{c}-0.001 \\
(0.170)\end{array}$ \\
\hline Constants & $\begin{array}{c}1.149 \\
(0.197)^{* * *}\end{array}$ & $\begin{array}{c}1.054 \\
(0.197)^{* * *}\end{array}$ & $\begin{array}{c}1.431 \\
(0.186)^{* * *}\end{array}$ & $\begin{array}{c}1.250 \\
(0.184)^{* * *}\end{array}$ \\
\hline $\begin{array}{l}\text { Log-likelihood } \\
\text { Wald chi2 } \\
\text { Prob > chi } 2\end{array}$ & $\begin{array}{c}-3361.32 \\
27.57 \\
0.000\end{array}$ & $\begin{array}{c}-3008.90 \\
29.68 \\
0.000\end{array}$ & $\begin{array}{c}-3735.62 \\
30.56 \\
0.000\end{array}$ & $\begin{array}{c}-3913.27 \\
23.40 \\
0.000\end{array}$ \\
\hline $\begin{array}{l}\text { Hausman Test } \\
\text { Prob> chi2 }\end{array}$ & & -1.60 & & 16.53 \\
\hline Observations & 534 & 534 & & 534 \\
\hline
\end{tabular}

Note: Standard errors are given in parentheses. ${ }^{* * *}, * *$ and $*$ denote significance at the $1 \%, 5 \%$ and $10 \%$ levels, respectively. 
Table 9. Effects of Cross-border Patents and Joint Patents (under GERD)

\begin{tabular}{|c|c|c|c|c|}
\hline \multirow[b]{2}{*}{ Variable } & \multicolumn{2}{|c|}{ Cross-border Patents } & \multicolumn{2}{|c|}{ Joint Patents } \\
\hline & $\begin{array}{c}\text { Fixed } \\
\text { Effects } \\
(1)\end{array}$ & $\begin{array}{l}\text { Random } \\
\text { Effects } \\
(2)\end{array}$ & $\begin{array}{c}\text { Fixed } \\
\text { Effects } \\
(3)\end{array}$ & $\begin{array}{c}\text { Random } \\
\text { Effects } \\
(4)\end{array}$ \\
\hline L1_Import & $\begin{array}{c}-0.739 \\
(0.318)^{* *}\end{array}$ & $\begin{array}{c}-0.837 \\
(0.318)^{* * *}\end{array}$ & $\begin{array}{l}-0.246 \\
(0.286)\end{array}$ & $\begin{array}{c}-0.373 \\
(0.288)\end{array}$ \\
\hline \multicolumn{5}{|l|}{ L1_Export } \\
\hline$L 1 \_T P$ & $\begin{array}{c}0.254 \\
(0.103)^{* *}\end{array}$ & $\begin{array}{c}0.264 \\
(0.102)^{* *}\end{array}$ & $\begin{array}{c}0.133 \\
(0.092)\end{array}$ & $\begin{array}{c}0.149 \\
(0.093)\end{array}$ \\
\hline$L 1 \_T R$ & $\begin{array}{c}-0.377 \\
(0.123)^{* * *}\end{array}$ & $\begin{array}{c}-0.359 \\
(0.121)^{* * *}\end{array}$ & $\begin{array}{c}-0.207 \\
(0.101)^{* *}\end{array}$ & $\begin{array}{c}-0.202 \\
(0.097)^{* *}\end{array}$ \\
\hline \multicolumn{5}{|l|}{ L1_FDI_in } \\
\hline L1_FDI_out & $\begin{array}{l}-0.011 \\
(0.168)\end{array}$ & $\begin{array}{l}-0.009 \\
(0.168)\end{array}$ & $\begin{array}{l}-0.185 \\
(0.159)\end{array}$ & $\begin{array}{l}-0.169 \\
(0.158)\end{array}$ \\
\hline L1_GERD & $\begin{array}{c}0.201 \\
(0.055)^{* * *}\end{array}$ & $\begin{array}{c}0.226 \\
(0.054)^{* * *}\end{array}$ & $\begin{array}{c}0.177 \\
(0.052)^{* * *}\end{array}$ & $\begin{array}{c}0.204 \\
(0.051)^{* * *}\end{array}$ \\
\hline$O E C D$ & $\begin{array}{c}0.033 \\
(0.189)\end{array}$ & $\begin{array}{c}0.098 \\
(0.186)\end{array}$ & $\begin{array}{c}-0.063 \\
(0.176)\end{array}$ & $\begin{array}{c}-0.009 \\
(0.171)\end{array}$ \\
\hline Constants & $\begin{array}{c}1.323 \\
(0.218)^{* * *}\end{array}$ & $\begin{array}{c}1.252 \\
(0.216)^{* * *}\end{array}$ & $\begin{array}{c}1.393 \\
(0.202)^{* * *}\end{array}$ & $\begin{array}{c}1.332 \\
(0.198)^{* * *}\end{array}$ \\
\hline $\begin{array}{l}\text { Log-likelihood } \\
\text { Wald chi2 } \\
\text { Prob > chi } 2\end{array}$ & $\begin{array}{c}-3360.95 \\
27.39 \\
0.000\end{array}$ & $\begin{array}{c}-3734.83 \\
30.90 \\
0.000\end{array}$ & $\begin{array}{c}-3530.04 \\
18.35 \\
0.005\end{array}$ & $\begin{array}{c}-3913.76 \\
22.11 \\
0.001\end{array}$ \\
\hline $\begin{array}{l}\text { Hausman Test } \\
\text { Prob> chi } 2\end{array}$ & $48.52 * * *$ & & & -12.52 \\
\hline Observations & 534 & 534 & 534 & 534 \\
\hline
\end{tabular}

Note: Standard errors are given in parentheses. ${ }^{* * *}, * *$ and $*$ denote significance at the $1 \%, 5 \%$ and $10 \%$ levels, respectively. 
Table 10. Effects of Cross-border Patents and Joint Patents (under GERD)

\begin{tabular}{|c|c|c|c|c|}
\hline \multirow[b]{2}{*}{ Variable } & \multicolumn{2}{|c|}{ Cross-border Patents } & \multicolumn{2}{|c|}{ Joint Patents } \\
\hline & $\begin{array}{c}\text { Fixed } \\
\text { Effects } \\
(1)\end{array}$ & $\begin{array}{l}\text { Random } \\
\text { Effects } \\
(2)\end{array}$ & $\begin{array}{c}\text { Fixed } \\
\text { Effects } \\
(3)\end{array}$ & $\begin{array}{c}\text { Random } \\
\text { Effects } \\
(4)\end{array}$ \\
\hline \multicolumn{5}{|l|}{ L1_Import } \\
\hline L1_Export & $\begin{array}{c}-0.290 \\
(0.263)\end{array}$ & $\begin{array}{l}-0.325 \\
(0.263)\end{array}$ & $\begin{array}{l}-0.098 \\
(0.238)\end{array}$ & $\begin{array}{l}-0.156 \\
(0.237)\end{array}$ \\
\hline$L 1 \_T P$ & $\begin{array}{c}0.197 \\
(0.100)^{* *}\end{array}$ & $\begin{array}{c}0.196 \\
(0.100)^{* *}\end{array}$ & $\begin{array}{c}0.110 \\
(0.090)\end{array}$ & $\begin{array}{c}0.114 \\
(0.091)\end{array}$ \\
\hline$L 1 \_T R$ & $\begin{array}{c}-0.355 \\
(0.121)^{* * *}\end{array}$ & $\begin{array}{c}-0.332 \\
(0.119)^{* * *}\end{array}$ & $\begin{array}{c}-0.198 \\
(0.100)^{* *}\end{array}$ & $\begin{array}{c}-0.188 \\
(0.096)^{* *}\end{array}$ \\
\hline \multicolumn{5}{|l|}{ L1_FDI_in } \\
\hline L1_FDI_out & $\begin{array}{l}-0.087 \\
(0.164)\end{array}$ & $\begin{array}{l}-0.097 \\
(0.163)\end{array}$ & $\begin{array}{l}-0.214 \\
(0.160)\end{array}$ & $\begin{array}{l}-0.210 \\
(0.158)\end{array}$ \\
\hline L1_GERD & $\begin{array}{c}0.197 \\
(0.055)^{* * *}\end{array}$ & $\begin{array}{c}0.221 \\
(0.055)^{* * *}\end{array}$ & $\begin{array}{c}0.175 \\
(0.052)^{* * *}\end{array}$ & $\begin{array}{c}0.201 \\
(0.051)^{* * *}\end{array}$ \\
\hline$O E C D$ & $\begin{array}{c}0.055 \\
(0.190)\end{array}$ & $\begin{array}{c}0.115 \\
(0.186)\end{array}$ & $\begin{array}{l}-0.057 \\
(0.176)\end{array}$ & $\begin{array}{c}-0.003 \\
(0.171)\end{array}$ \\
\hline Constants & $\begin{array}{c}1.187 \\
(0.215)^{* * *}\end{array}$ & $\begin{array}{c}1.100 \\
(0.213)^{* * *}\end{array}$ & $\begin{array}{c}1.351 \\
(0.198)^{* * *}\end{array}$ & $\begin{array}{c}1.274 \\
(0.195)^{* * *}\end{array}$ \\
\hline $\begin{array}{l}\text { Log-likelihood } \\
\text { Wald chi2 } \\
\text { Prob > chi } 2\end{array}$ & $\begin{array}{c}-3363.24 \\
23.58 \\
0.000\end{array}$ & $\begin{array}{c}-3737.77 \\
26.05 \\
0.000\end{array}$ & $\begin{array}{c}-3530.33 \\
17.82 \\
0.007\end{array}$ & $\begin{array}{c}-3914.41 \\
20.93 \\
0.002\end{array}$ \\
\hline $\begin{array}{l}\text { Hausman Test } \\
\text { Prob> chi } 2\end{array}$ & & -52.95 & & -38.47 \\
\hline Observations & 534 & 534 & 534 & 534 \\
\hline
\end{tabular}

Note: Standard errors are given in parentheses. ${ }^{* * *}, * *$ and $*$ denote significance at the $1 \%, 5 \%$ and $10 \%$ levels, respectively. 
Table 11. Effects of Cross Patents and Joint Patents (Decomposition of R\&D)

\begin{tabular}{|c|c|c|c|c|}
\hline & \multicolumn{2}{|c|}{ Cross-border Patents } & \multicolumn{2}{|c|}{ Joint Patents } \\
\hline & $\begin{array}{l}\text { Fixed } \\
\text { Effects } \\
(1)\end{array}$ & $\begin{array}{l}\text { Random } \\
\text { Effects } \\
\text { (2) }\end{array}$ & $\begin{array}{l}\text { Fixed } \\
\text { Effects } \\
(3)\end{array}$ & $\begin{array}{l}\text { Random } \\
\text { Effects } \\
(4)\end{array}$ \\
\hline \multicolumn{5}{|l|}{ L1_Import } \\
\hline \multicolumn{5}{|l|}{ L1_Export } \\
\hline L1_TP & $\begin{array}{c}0.281 \\
(0.097)^{* * *}\end{array}$ & $\begin{array}{c}0.284 \\
(0.096)^{* * *}\end{array}$ & $\begin{array}{c}0.202 \\
(0.082)^{* *}\end{array}$ & $\begin{array}{c}0.207 \\
(0.082)^{* *}\end{array}$ \\
\hline$L 1 \_T R$ & $\begin{array}{c}-0.425 \\
(0.120)^{* * *}\end{array}$ & $\begin{array}{c}-0.398 \\
(0.117) * * *\end{array}$ & $\begin{array}{c}-0.306 \\
(0.100)^{* * *}\end{array}$ & $\begin{array}{c}-0.287 \\
(0.096) * * *\end{array}$ \\
\hline L1_FDI_in & $\begin{array}{c}-0.504 \\
(0.214)^{* *}\end{array}$ & $\begin{array}{c}-0.541 \\
(0.213)^{* *}\end{array}$ & $\begin{array}{c}-0.390 \\
(0.221)^{*}\end{array}$ & $\begin{array}{c}-0.441 \\
(0.218)^{* *}\end{array}$ \\
\hline L1_FDI_out & $\begin{array}{c}0.128 \\
(0.189)\end{array}$ & $\begin{array}{c}0.129 \\
(0.187)\end{array}$ & $\begin{array}{l}-0.065 \\
(0.204)\end{array}$ & $\begin{array}{l}-0.052 \\
(0.199)\end{array}$ \\
\hline L1_BERD & $\begin{array}{c}0.135 \\
(0.078)^{*}\end{array}$ & $\begin{array}{c}0.149 \\
(0.077)^{*}\end{array}$ & $\begin{array}{c}0.023 \\
(0.074)\end{array}$ & $\begin{array}{c}0.046 \\
(0.073)\end{array}$ \\
\hline L1_GOVERD & $\begin{array}{c}-0.100 \\
(0.425)\end{array}$ & $\begin{array}{c}0.218 \\
(0.421)\end{array}$ & $\begin{array}{c}0.076 \\
(0.383)\end{array}$ & $\begin{array}{c}0.152 \\
(0.378)\end{array}$ \\
\hline L1_HERD & $\begin{array}{c}0.736 \\
(0.336)^{* *}\end{array}$ & $\begin{array}{c}0.817 \\
(0.331)^{* *}\end{array}$ & $\begin{array}{c}1.277 \\
(0.299)^{* * *}\end{array}$ & $\begin{array}{c}1.320 \\
(0.295)^{* * *}\end{array}$ \\
\hline$O E C D$ & $\begin{array}{l}-0.029 \\
(0.197)\end{array}$ & $\begin{array}{c}0.026 \\
(0.194)\end{array}$ & $\begin{array}{l}-0.159 \\
(0.181)\end{array}$ & $\begin{array}{l}-0.099 \\
(0.176)\end{array}$ \\
\hline Constant & $\begin{array}{c}1.100 \\
(0.221)^{* * *}\end{array}$ & $\begin{array}{c}0.974 \\
(0.222)^{* * *}\end{array}$ & $\begin{array}{c}1.284 \\
(0.207)^{* * *}\end{array}$ & $\begin{array}{c}1.172 \\
(0.206)^{* * *}\end{array}$ \\
\hline $\begin{array}{l}\text { Log-likelihood } \\
\text { Wald chi2 } \\
\text { Prob > chi } 2\end{array}$ & $\begin{array}{c}-3228.23 \\
29.88 \\
0.000\end{array}$ & $\begin{array}{c}-3610.97 \\
33.15 \\
0.000\end{array}$ & $\begin{array}{c}-3391.82 \\
34.37 \\
0.000\end{array}$ & $\begin{array}{c}-3374.14 \\
37.89 \\
0.000\end{array}$ \\
\hline $\begin{array}{l}\text { Hausman Test } \\
\text { Prob> chi2 }\end{array}$ & & -42.22 & $32.05 * * *$ & \\
\hline Observation & 515 & 515 & 515 & 515 \\
\hline
\end{tabular}

Note: Standard errors are given in parentheses. ${ }^{* * *},{ }^{* *}$ and $*$ denote significance at the $1 \%, 5 \%$ and $10 \%$ levels, respectively. 
Table 12. Effects of Cross Patents and Joint Patents (Decomposition of R\&D)

\begin{tabular}{|c|c|c|c|c|}
\hline & \multicolumn{2}{|c|}{ Cross-border Patents } & \multicolumn{2}{|c|}{ Joint Patents } \\
\hline & $\begin{array}{l}\text { Fixed } \\
\text { Effects } \\
(1)\end{array}$ & $\begin{array}{l}\text { Random } \\
\text { Effects } \\
(2)\end{array}$ & $\begin{array}{l}\text { Fixed } \\
\text { Effects } \\
(3)\end{array}$ & $\begin{array}{l}\text { Random } \\
\text { Effects } \\
(4)\end{array}$ \\
\hline L1_Import & $\begin{array}{c}-0.836 \\
(0.330)^{* *}\end{array}$ & $\begin{array}{c}-0.822 \\
(0.328)^{* *}\end{array}$ & $\begin{array}{l}-0.313 \\
(0.293)\end{array}$ & $\begin{array}{l}-0.419 \\
(0.294)\end{array}$ \\
\hline \multicolumn{5}{|l|}{ L1_Export } \\
\hline$L 1 \_T P$ & $\begin{array}{c}0.297 \\
(0.104) * * *\end{array}$ & $\begin{array}{c}0.385 \\
(0.109)^{* * *}\end{array}$ & $\begin{array}{c}0.188 \\
(0.089)^{* *}\end{array}$ & $\begin{array}{c}0.202 \\
(0.090)^{* *}\end{array}$ \\
\hline$L 1 \_T R$ & $\begin{array}{c}-0.438 \\
(0.128)^{* * *}\end{array}$ & $\begin{array}{c}-0.433 \\
(0.122)^{* * *}\end{array}$ & $\begin{array}{c}-0.307 \\
(0.108)^{* * *}\end{array}$ & $\begin{array}{c}-0.292 \\
(0.106)^{* * *}\end{array}$ \\
\hline \multicolumn{5}{|l|}{ L1_FDI_in } \\
\hline L1_FDI_out & $\begin{array}{l}-0.040 \\
(0.175)\end{array}$ & $\begin{array}{c}0.233 \\
(0.201)\end{array}$ & $\begin{array}{l}--0.267 \\
(0.168)\end{array}$ & $\begin{array}{l}-0.264 \\
(0.168)\end{array}$ \\
\hline L1_BERD & $\begin{array}{c}0.170 \\
(0.077)^{* *}\end{array}$ & $\begin{array}{c}0.175 \\
(0.076)^{* *}\end{array}$ & $\begin{array}{c}0.041 \\
(0.075)\end{array}$ & $\begin{array}{c}0.068 \\
(0.074)\end{array}$ \\
\hline L1_GOVERD & $\begin{array}{l}-0.109 \\
(0.440)\end{array}$ & $\begin{array}{c}0.045 \\
(0.431)\end{array}$ & $\begin{array}{l}-0.024 \\
(0.391)\end{array}$ & $\begin{array}{c}0.044 \\
(0.387)\end{array}$ \\
\hline L1_HERD & $\begin{array}{c}0.618 \\
(0.336)^{*}\end{array}$ & $\begin{array}{c}0.775 \\
(0.328)^{* *}\end{array}$ & $\begin{array}{c}1.216 \\
(0.302)^{* * *}\end{array}$ & $\begin{array}{c}1.250 \\
(0.298)^{* * *}\end{array}$ \\
\hline$O E C D$ & $\begin{array}{l}-0.015 \\
(0.197)\end{array}$ & $\begin{array}{l}-0.003 \\
(0.193)\end{array}$ & $\begin{array}{l}-0.159 \\
(0.182)\end{array}$ & $\begin{array}{l}-0.102 \\
(0.177)\end{array}$ \\
\hline Constant & $\begin{array}{c}1.365 \\
(0.252)^{* * *}\end{array}$ & $\begin{array}{c}1.268 \\
(0.250)^{* * *}\end{array}$ & $\begin{array}{c}1.376 \\
(0.228)^{* * *}\end{array}$ & $\begin{array}{c}1.292 \\
(0.225)^{* * *}\end{array}$ \\
\hline $\begin{array}{l}\text { Log-likelihood } \\
\text { Wald chi2 } \\
\text { Prob > chi2 }\end{array}$ & $\begin{array}{c}-3237.48 \\
29.62 \\
0.000\end{array}$ & $\begin{array}{c}-3607.61 \\
37.84 \\
0.000\end{array}$ & $\begin{array}{c}-3392.74 \\
31.06 \\
0.000\end{array}$ & $\begin{array}{c}-3775.03 \\
34.38 \\
0.000\end{array}$ \\
\hline $\begin{array}{l}\text { Hausman Test } \\
\text { Prob> chi2 }\end{array}$ & & 3.97 & & 13.51 \\
\hline Observation & 515 & 515 & 515 & 515 \\
\hline
\end{tabular}

Note: Standard errors are given in parentheses. ${ }^{* * *},{ }^{* *}$ and $*$ denote significance at the $1 \%, 5 \%$ and $10 \%$ levels, respectively. 
Table 13. Effects of Cross Patents and Joint Patents (Decomposition of R\&D)

\begin{tabular}{|c|c|c|c|c|}
\hline & \multicolumn{2}{|c|}{ Cross-border Patents } & \multicolumn{2}{|c|}{ Joint Patents } \\
\hline & $\begin{array}{l}\text { Fixed } \\
\text { Effects } \\
(1)\end{array}$ & $\begin{array}{l}\text { Random } \\
\text { Effects } \\
(2)\end{array}$ & $\begin{array}{l}\text { Fixed } \\
\text { Effects } \\
(3)\end{array}$ & $\begin{array}{l}\text { Random } \\
\text { Effects } \\
(4)\end{array}$ \\
\hline \multicolumn{5}{|l|}{ L1_Import } \\
\hline L1_Export & $\begin{array}{l}-0.327 \\
(0.272)\end{array}$ & $\begin{array}{l}-0.348 \\
(0.271)\end{array}$ & $\begin{array}{l}-0.120 \\
(0.241)\end{array}$ & $\begin{array}{l}-0.159 \\
(0.241)\end{array}$ \\
\hline L1_TP & $\begin{array}{c}0.235 \\
(0.101)^{* *}\end{array}$ & $\begin{array}{c}0.235 \\
(0.100)^{* *}\end{array}$ & $\begin{array}{c}0.158 \\
(0.087)^{*}\end{array}$ & $\begin{array}{c}0.160 \\
(0.875)^{*}\end{array}$ \\
\hline L1_TR & $\begin{array}{c}-0.411 \\
(0.126)^{* * *}\end{array}$ & $\begin{array}{c}-0.384 \\
(0.123) * * *\end{array}$ & $\begin{array}{c}-0.293 \\
(0.106)^{* * *}\end{array}$ & $\begin{array}{c}-0.272 \\
(0.103)^{* * *}\end{array}$ \\
\hline \multicolumn{5}{|l|}{ L1_FDI_in } \\
\hline L1_FDI_out & $\begin{array}{c}0.110 \\
(0.170)\end{array}$ & $\begin{array}{l}-0.122 \\
(0.171)\end{array}$ & $\begin{array}{c}-0.300 \\
(0.168)^{*}\end{array}$ & $\begin{array}{c}-0.308 \\
(0.168)^{*}\end{array}$ \\
\hline$L 1 \_B E R D$ & $\begin{array}{c}0.157 \\
(0.079)^{* *}\end{array}$ & $\begin{array}{c}0.171 \\
(0.077)^{* *}\end{array}$ & $\begin{array}{c}0.036 \\
(0.076)\end{array}$ & $\begin{array}{c}0.060 \\
(0.074)\end{array}$ \\
\hline L1_GOVERD & $\begin{array}{l}-0.016 \\
(0.436)\end{array}$ & $\begin{array}{c}0.144 \\
(0.432)\end{array}$ & $\begin{array}{c}0.016 \\
(0.388)\end{array}$ & $\begin{array}{c}0.090 \\
(0.384)\end{array}$ \\
\hline L1_HERD & $\begin{array}{c}0.635 \\
(0.341)^{*}\end{array}$ & $\begin{array}{c}0.713 \\
(0.337)^{* *}\end{array}$ & $\begin{array}{c}1.220 \\
(0.303)^{* * *}\end{array}$ & $\begin{array}{c}1.257 \\
(0.299) * * *\end{array}$ \\
\hline$O E C D$ & $\begin{array}{c}0.000 \\
(0.198)\end{array}$ & $\begin{array}{c}0.055 \\
(0.194)\end{array}$ & $\begin{array}{l}-0.152 \\
(0.183)\end{array}$ & $\begin{array}{l}-0.096 \\
(0.177)\end{array}$ \\
\hline Constant & $\begin{array}{c}1.174 \\
(0.246)^{* * *}\end{array}$ & $\begin{array}{c}1.049 \\
(0.245)^{* * *}\end{array}$ & $\begin{array}{c}1.310 \\
(0.223)^{* * *}\end{array}$ & $\begin{array}{c}1.210 \\
(0.221)^{* * *}\end{array}$ \\
\hline $\begin{array}{l}\text { Log-likelihood } \\
\text { Wald chi2 } \\
\text { Prob > chi2 }\end{array}$ & $\begin{array}{c}-3240.20 \\
25.12 \\
0.002\end{array}$ & $\begin{array}{c}-3613.26 \\
27.65 \\
0.000\end{array}$ & $\begin{array}{c}-3393.20 \\
30.36 \\
0.000\end{array}$ & $\begin{array}{c}-3775.87 \\
33.09 \\
0.000\end{array}$ \\
\hline $\begin{array}{l}\text { Hausman Test } \\
\text { Prob> chi2 }\end{array}$ & & -287.13 & & 8.07 \\
\hline Observation & 515 & 515 & 515 & 515 \\
\hline
\end{tabular}

Note: Standard errors are given in parentheses. ${ }^{* * *},{ }^{* *}$ and $*$ denote significance at the $1 \%, 5 \%$ and $10 \%$ levels, respectively. 